\title{
Article \\ A dynamical downscaling projection of future climate change in the Laurentian Great Lakes region using a coupled air-lake model
}

\author{
Chuliang Xiao ${ }^{1, *}$, Brent M. Lofgren ${ }^{2}$, Jia Wang ${ }^{2}$ and Philip Y. Chu ${ }^{2}$ \\ 1 Cooperative Institute for Great Lakes Research (CIGLR), University of Michigan, Ann Arbor, Michigan, \\ 481087, USA \\ 2 NOAA Great Lakes Environmental Research Laboratory, Ann Arbor, Michigan 48108, USA \\ * Correspondence: cxiao@umich.edu; Tel.: +1-734-741-2392
}

Version July 25, 2018 submitted to

\begin{abstract}
Large water bodies such as the Laurentian Great Lakes have significant influences on local and regional climate through their unique physical features. Due to the coarse spatial resolution of general circulation models (GCMs), the Great Lakes are geometrically ignored in most GCMs. Thus, the dynamical downscaling technique serves as a necessary and feasible solution to bridge the gap. The Weather Research and Forecasting model (WRF) with an updated lake scheme is employed to downscale from a GCM, GFDL-CM3. The WRF-Lake's performance is evaluated against observations, the GCM, as well as 23 other GCMs. Results show that the coupled air-lake model, with a fine spatial resolution and realistic lake bathymetries, reproduced a more reasonable spatiotemporal climatology than GCMs, as well as the lake-induced characteristics that were missed in GCMs. With lakes present, the seasonal variability of air temperature was reduced in WRF-Lake relative to GFDL-CM3, especially in summer. A reduced air temperature trend, about $4.5^{\circ} \mathrm{C} / 100$ year in the 21st century, was projected in WRF-Lake. The seasonal evolutions of lake surface temperature and lake ice coverage were well captured by the lake model. The lake surface temperature was projected to be warming by $3.5-4{ }^{\circ} \mathrm{C}$ and the lake ice diminishing by $58.9 \%$ - $86 \%$. Those results brought by the WRF-Lake model suggest that a fine resolution of the topography and the incorporation of the lake-atmosphere interactions are crucial to improve the understanding of the climate and climate change in the Great Lakes region.
\end{abstract}

Keywords: Dynamic Downscaling; WRF-Lake; CMIP5; Great Lakes

\section{Introduction}

As the largest group of freshwater bodies in the world, the Laurentian Great Lakes possess a total water surface area of $244000 \mathrm{~km}^{2}$, supporting one of the most populated coastal areas within their watershed of more than $777000 \mathrm{~km}^{2}$. The Great Lakes play a crucial role in shaping the local and regional hydroclimate [1-5]. This region has been of significant interest in both the observed climate change and the ongoing process of global warming in terms of air/lake temperature rising, lake ice diminishing, severe precipitation, water level response, and associated socioeconomic effects [6-8].

Compared with the surrounding land, the Great Lakes are characterized with unique physical features including large thermal capacity, low albedo, and low friction. In the ice-free seasons, the lakes, acting as a massive heat reservoir and moisture source, interact with the atmosphere and cause profound influences on the local weather phenomenon, such as lake-effect snow [9-11], lake-effect rainfall [12], and lake-induced cyclogenesis [13,14]. Besides those local effects generated by individual lakes, the combined forcing from all of the Great Lakes can cause a remarkable influence on synoptic-scale cyclones [15-17]. Due to the vastness of these water bodies, the Great Lakes can significantly affect the regional climate. The lakes generally reduce the annual range and diurnal cycle of air temperature across the basin [2,5]. The seasonality of precipitation is also modified by the presence of the Great Lakes in the forms of both rainfall and snowfall. In contrast to most regions 
dominated by land where the precipitation is primarily derived from moisture transport from long distances, precipitation in the Great Lakes basin is controlled by local moisture evaporated from the lakes [18,19]. Precipitation downwind of the lakes is enhanced during late autumn-early winter when cold and dry air masses pass over the warm water surface, sometimes resulting in heavy snowfall on the lee side of the lakes.

To study the Great Lakes' influence on local and regional weather and climate, numerical simulations employing regional or global circulation models (RCMs/GCMs) provide feasible approaches. Early numerical experiments $[20,21]$ showed that the Great Lakes generally reduced the surface pressure and enhanced the precipitation in winter. To assess the lakes' impacts on basin-wide precipitation, Bates et al. [2] applied a regional model to perform two experiments wherein the impacts of the Great Lakes were included and then excluded. Sousounis and Fritsch [15] conducted comparison simulations on a weak synoptic-scale low in late autumn and found that the Great Lakes enhanced the surface pressure deepening rate. Besides the aforementioned short-term simulations, other studies have been carried out for long-term integration by employing climate models. Because of the computational limitation, GCM experiments were conducted at coarse resolution where the Great Lakes are geometrically idealized into separate grid cells [4,22]. In spite of this disadvantage, the substantial influences of temperature modulations induced by the water mass were generally detected in multi-year simulations though the lake impacts were underestimated. Thus, a methodology of using RCMs, also known as dynamical downscaling, serves as powerful tool to fill the gap [23]. Nested from coarse GCMs, RCMs not only fill in meteorological information from GCMs input at finer resolution but, more importantly, also provide customizable features including specified domains, sophisticated topographies, and optimized parameterizations for a particular region of interest. Derived from atmospheric stand-alone models, RCMs have developed considerably by integrating the interactions of atmosphere, land, ocean, sea ice, and biosphere. Several sophisticated land surface models are being added into RCMs as componential modules. However, the lakes have remained non-existent or extremely simplified in most land surface models.

Table 1. Summary of prior studies with RCM-lake modeling systems in the Great Lakes Offline: the lake model was post-run; One-way: the lake model was forced by the RCM; Fully: the lake scheme was embedded in the RCM.

\begin{tabular}{|c|c|c|c|c|c|c|}
\hline No. & GCM/Reanalysis & RCM & Lake & Coupling & Projection & Reference \\
\hline 1 & CCSM3 & MM5 & Extrapolation & - & - & Zhong et al. [24] \\
\hline 2 & $\begin{array}{c}\text { CESM } \\
\text { ERA-Interim }\end{array}$ & WRF & Extrapolation & - & - & Mallard et al. [25] \\
\hline 3 & $\begin{array}{l}\text { GFDL-ESM2M } \\
\text { HadGEM2-ES }\end{array}$ & RegCM4 & Extrapolation & - & - & Bryan et al. [19] \\
\hline 4 & CGCM & CRCM & Mixed-layer & fully & - & Goyette et al. [26] \\
\hline 5 & CCSM3 & WRF & FLake forcing & offline & Yes & Gula and Peltier [27] \\
\hline 6 & $\begin{array}{l}\text { NCEP/DOE II } \\
\text { NCEP/NCAR }\end{array}$ & WRF & FLake & fully & - & Mallard et al. [28] \\
\hline 7 & $\begin{array}{l}\text { MIRCO5 } \\
\text { CNRM }\end{array}$ & RegCM4 & Hostetler (50 m) & fully & Yes & Notaro et al. [29] \\
\hline 8 & GEM & RDPS & NEMO & 1-way & - & Dupont et al. [30] \\
\hline 9 & ERA-Interim & RegCM3 & FVCOM & fully & - & Xue et al. [31] \\
\hline 10 & CESM1 & WRF & FLake & fully & Yes & Peltier et al. [32] \\
\hline
\end{tabular}
temperature (LST) is a key point in the downscaling process (Table 1). If no lake component was implemented in the Great Lakes, a "search" option in RCMs was employed to extrapolate LST from the closest water point with valid data, e.g. Hudson Bay and the Atlantic Ocean [19,24,25,33]. Another solution is to use a lake model to calculate LST. A variety of lake models with different complexities has been performed in the Great Lakes: a thermodynamic model, the Mixed-Layer Model [26]; a 
relatively simple 2-layer model based on similarity theory, FLake [27,28,32]; a thermal diffusion model with parameterized eddy diffusivity, the 1-dimensional (1-D) Hostetler Model [29,34]; and a 3-D ocean general circulation model, NEMO (Nucleus for European Modelling of the Ocean) [30] and FVCOM (Finite Volume Community Ocean Model) [31]. According to the methods of data exchange between RCMs and lake models, those downscaling studies can be categorized into 3 types: (1) offline, the lake model was run to provide LST for the RCM [27]; (2) one-way, the lake model was fed by the RCM [30]; (3) fully coupled, the lake model was a module embedded in the RCM [26,28,29,31,32].

\section{Land Area Fraction}

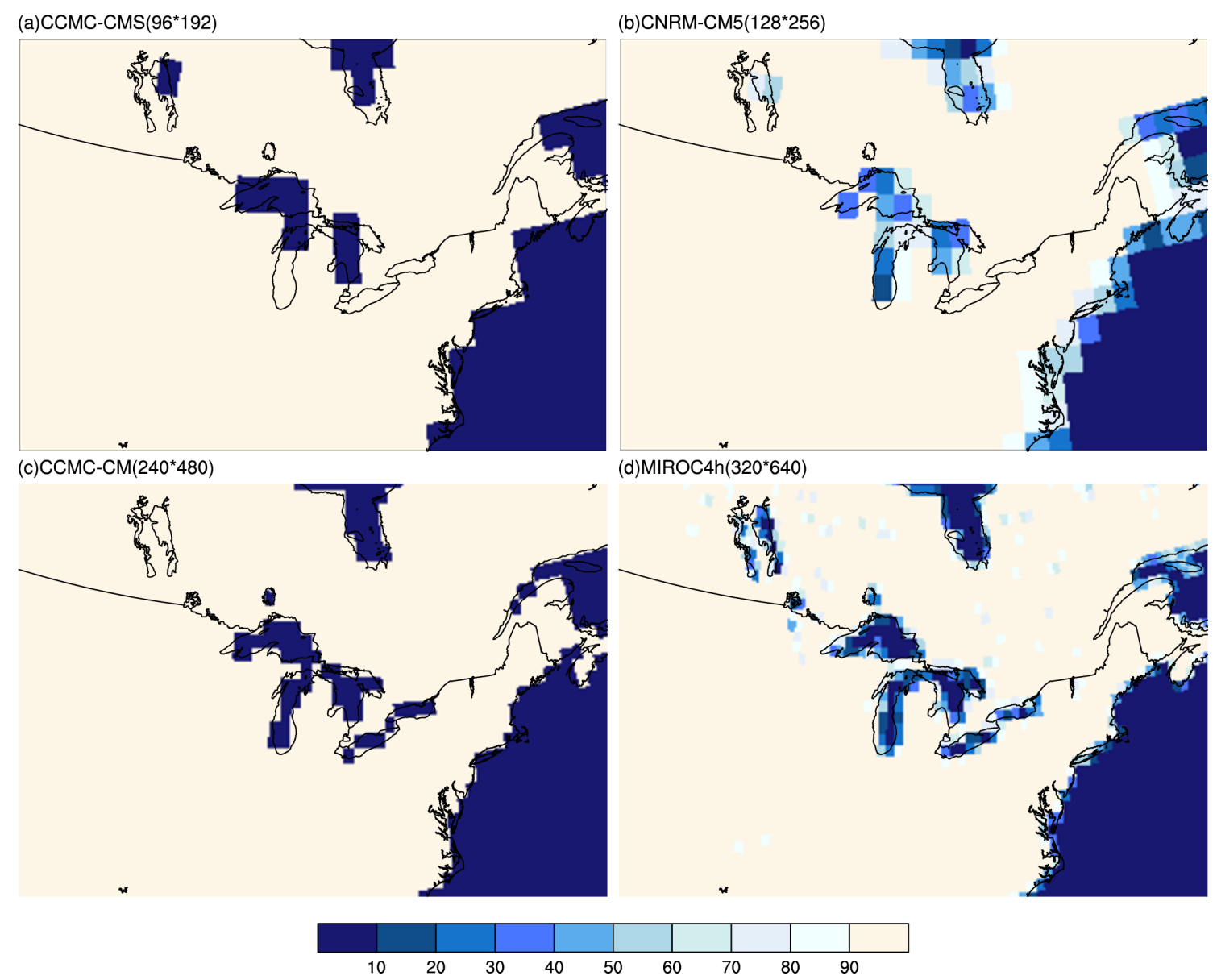

Figure 1. The land area fraction in 4 CMIP5 models that can partially resolve the Great Lakes.

In this study, we applied a regional model, the Weather Research and Forecasting (WRF) model with the Advanced Research WRF (ARW) dynamic core [35] and conducted a downscaling study in the Great Lake region. Using WRF as an RCM as in Gula and Peltier [27], our study implemented a fully coupled WRF-Lake model in the Great Lakes, while the FLake in Gula and Peltier [27] was driven offline. In contrast to the hydrostatic RegCM4 in Notaro et al. [29], WRF here served as a nonhydrostatic option. Gula and Peltier [27] had a future temporal scope of 11 years (2050-2060); Notaro et al. [29] focused on two twenty-year periods (2040-2059 and 2080-2099). We have completed a continuous future projection run from 2006 to 2100.

The remainder of this paper is organized as follows. Section 2 describes model configurations, experimental designs, and datasets. The results are presented in section 3. Discussion and conclusions are provided in sections 4 . 


\section{Model description}

\subsection{Overview of CMIP5}

To conduct a dynamical downscaling study in the Great Lakes region, the fifth phase of the Coupled Model Intercomparison Project (CMIP5) [36] is used to force the WRF model. More than 60 coupled GCMs (more precisely, earth system models) have participated in the CMIP5 ensemble, developed by 30 plus institutes around the world. Based on the availability of CMIP5 archives at the moment when we started the study, we selected 24 models with full records of historical simulation (1970-2005) and future projection (2006-2100) (Table 2). Their spatial spacing ranges from $280 \mathrm{~km}$ (BCC-CSM1-1) to $60 \mathrm{~km}$ (MIROC4h). The Great Lakes are not well represented in CMIP5 models. We examined all available CMIP5 models and found that only 4 models can partially recognize the lakes as water bodies (Fig. 1). Even in MIROC4h with the finest resolution, the Great Lakes are still poorly resolved. A high-resolution RCM with well-represented lakes becomes necessary to produce a credible projection in the Great Lakes region.

Table 2. The list of CMIP5 models used for multiple-model ensemble mean (MME) Four CMIP4 models, MIRCO4h, CMCC-CM, CNRM-CM5, and CMCC-CMS can partially resolve the Great Lakes. GFDL-CM3 is selected to drive the WRF/Lake model in our dynamic downscaling study.

\begin{tabular}{cc|cc}
\hline Model & Grid & Model & Grid \\
\hline BCC-CSM1-1-M & $160^{*} 320$ & GISS-E2-R & $90^{*} 144$ \\
BCC-CSM1-1 & $64^{*} 128$ & HadGEM2-AO & $145^{*} 192$ \\
CMCC-CMS & $96^{*} 192$ & INMCM4 & $120^{*} 180$ \\
CMCC-CM & $240^{*} 480$ & IPSL-CM5A-LR & $96^{*} 96$ \\
CNRM-CM5 & $128^{*} 256$ & IPSL-CM5A-MR & $143^{*} 144$ \\
CanESM2 & $64^{*} 128$ & IPSL-CM5B-LR & $96^{*} 96$ \\
GFDL-CM3 & $90^{*} 144$ & MIROC4h & $320^{*} 640$ \\
GFDL-ESM2G & $90^{*} 144$ & MPI-ESM-LR & $96^{*} 192$ \\
GFDL-ESM2M & $90^{*} 144$ & MPI-ESM-MR & $96^{*} 192$ \\
GISS-E2-H-CC & $90^{*} 144$ & MRI-CGCM3 & $96^{*} 192$ \\
GISS-E2-H & $90^{*} 144$ & NorESM1-ME & $96^{*} 144$ \\
GISS-E2-R-CC & $90^{*} 144$ & NorESM1-M & $96^{*} 144$ \\
\hline
\end{tabular}

\subsection{Model descriptions}

The RCM employed in this study is the WRF-ARW model version 3.6.1 (referred to as WRF) interactively coupled with a 1-D lake model. As a limited area, non-hydrostatic model, with a terrain-following eta-coordinate mesoscale modeling system, WRF has been designed to serve both operational forecasting and atmospheric research needs. The model was run on a single domain with a grid spacing of $30 \mathrm{~km}$ (Fig. 2) and 31 vertical levels, which was directly nested from a CMIP5 model. Given the substantial inter-model spread in CMIP5, a possible way to sample the uncertainty is to perform a large set of downscaling ensembles. However, this requires enormous computational resources that would be far beyond our current capability. In this study, a dynamical downscaling realization from one CMIP5 model, GFDL-CM3 (Donner et al. 2011), has been carried out. GFDL-CM3 has a spatial resolution sufficient to satisfy the nesting ratio (about 6.5:1) between the parent GCM $\left(2^{\circ} \times 2.5^{\circ}\right)$ and $30-\mathrm{km}$ RCM. Meanwhile, the historical climatology and future projection of GFDL-CM3 actually ranges in the middle of the 24 CMIP5 models, indicating GFDL-CM3's credibility to be representative (see details in section $3 \mathrm{~d}$ ). The results from WRF-Lake and GFDL-CM3 were compared with the multiple-model ensemble mean (MME) of the 24 CMIP5 models. 


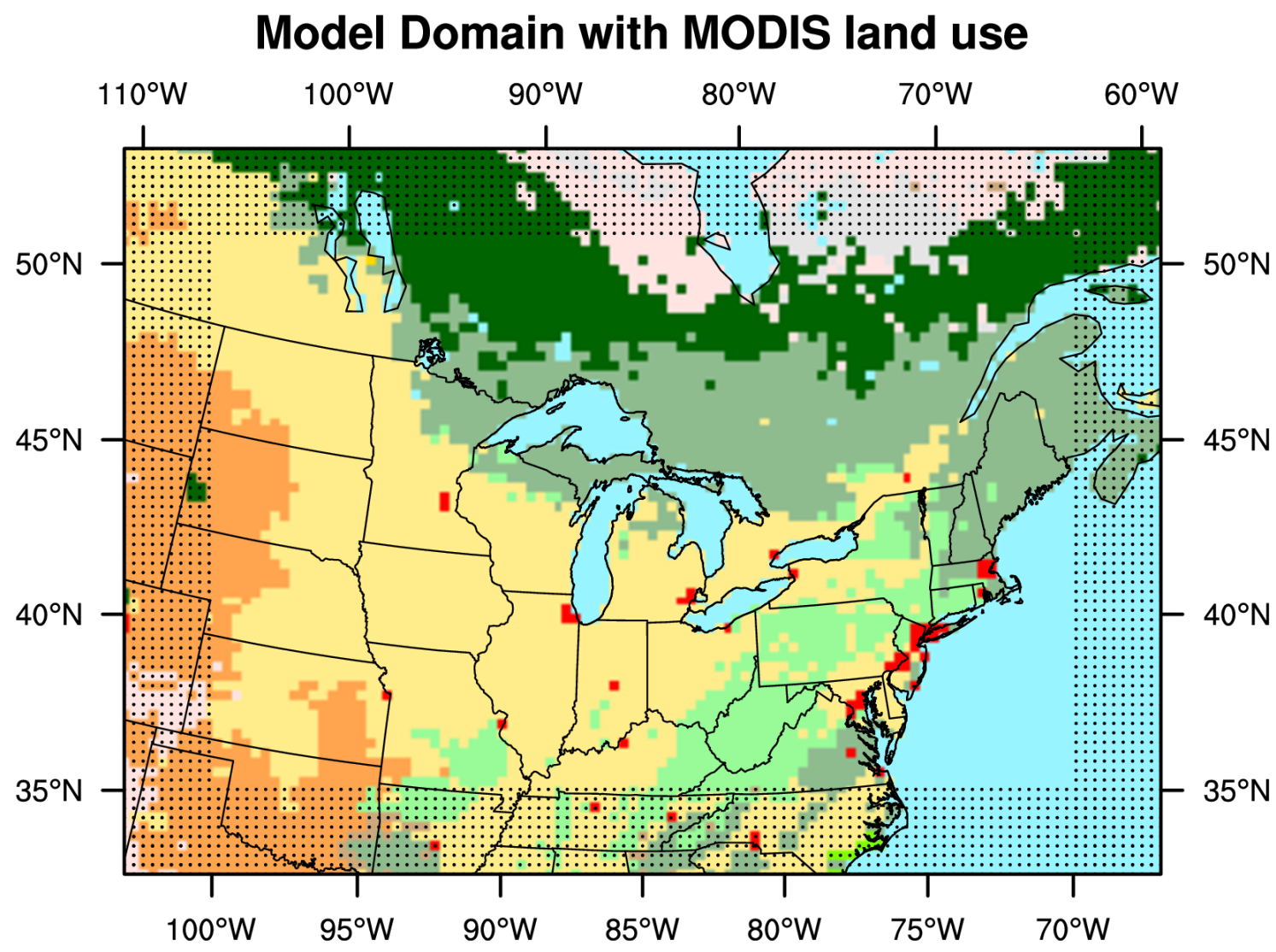

\begin{tabular}{|l|l|l|l|l|l|l|l|l|l|l|l|l|l|l|l|l|l|l|}
\hline 2 & 3 & 4 & 5 & 6 & 7 & 8 & 9 & 10 & 11 & 12 & 13 & 14 & 15 & 16 & 17 & 18 & 19 & 20 \\
\hline
\end{tabular}

1 Evergreen Needleleaf 5 Mixed Forest

2 Evergreen Broadleaf 6 Closed Shrublands

3 Deciduous Needleleaf 7 Open Shrublands

4 Deciduous Broadleaf 8 Woody Savannas
9 Savannas

10 Grasslands

11 Permanent

12 Croplands
13 Urban and Built-up 17 Water Bodies

14 Cropland Mosaics 18 Tundra

19 Mixed Tundra

16 Bare Soil and Rocks 20 Barren Tundra

Figure 2. The WRF model domain with MODIS land coverage. The lateral buffer zone is marked with dots.

WRF used grid and subgrid moisture processes parameterized by WSM5 (WRF Single-Moment 5-class scheme) microphysics scheme [37] and KF (Kain-Fritsch) cumulus convection scheme [38]. Shortwave and longwave radiative processes were represented by the RRTMG schemes (Rapid Radiative Transfer Model for GCMs) [39]. The MYJ (Mellor-Yamada-Janjic) scheme [40] was chosen for the planetary boundary layer. The land component employed an updated CLM (Community Land Model) [41]. More details of those parameterization schemes are documented in the WRF User Guide [35]. The domain's lateral boundary was formulated with a 1-point specified zone and a 9-point relaxation zone (Fig. 2). As in Gula and Peltier [27], a weak spectral nudging (maximum wave number 3) was applied at all levels above the planetary boundary layer, preventing synoptic-scale climate drift and also maintaining the objective of downscaling to be consistent with the GCM. 


\section{Lake Bathymetry Grids in WRF}

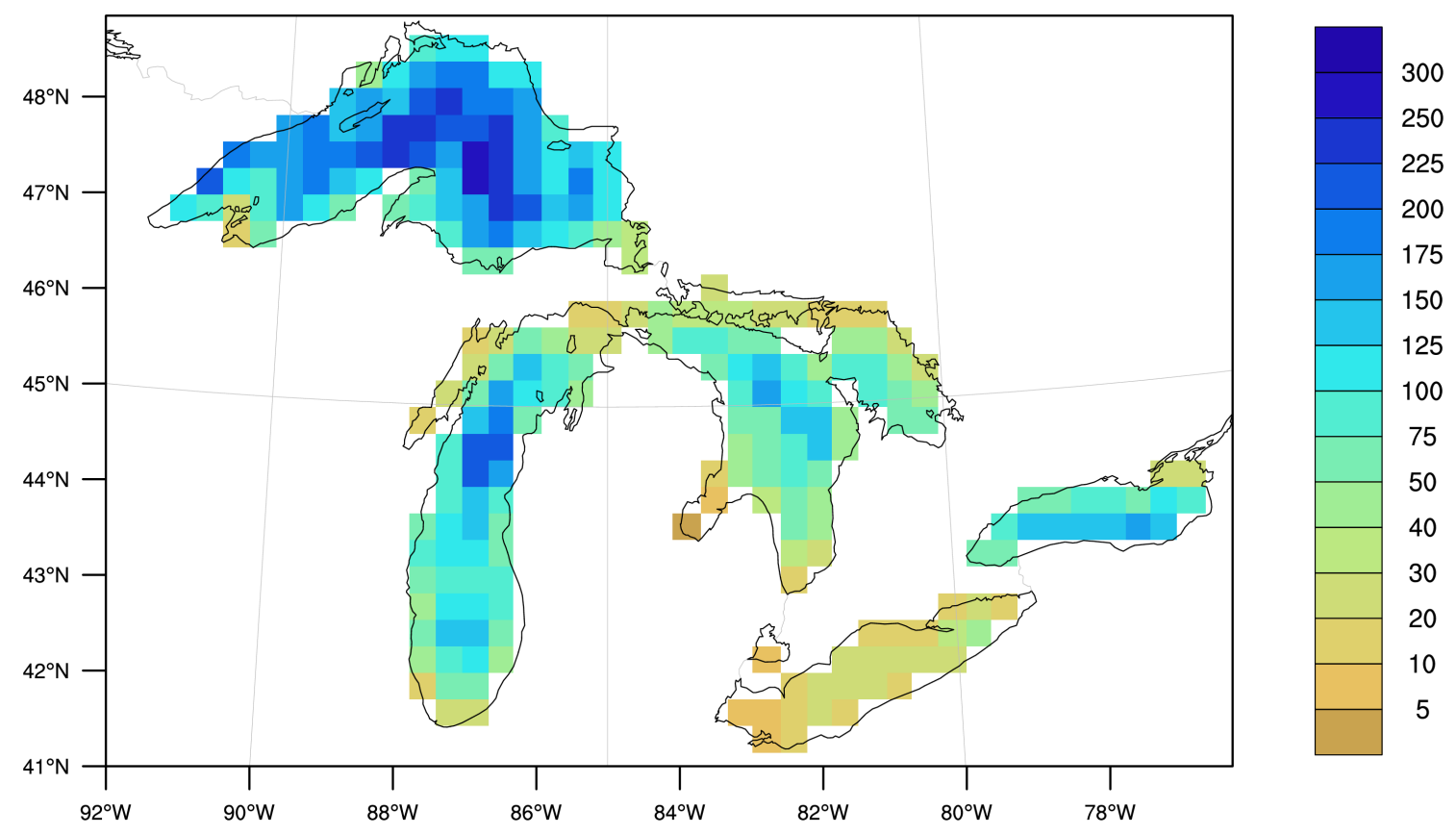

Figure 3. The bathymetry grids (m) of the Great Lakes in the WRF/Lake model.

\subsection{Lake model}

Starting with version 3.6, WRF has been released with a thermal diffusion lake model. The lake scheme [42] was obtained from the CLM 4.5 [41] with calibrations by Gu et al. [43], based on the original concept of Hostetler and Bartlein [44]. It is a 1-D mass and energy balance scheme with 20 model layers, consisting of up to 5 snow layers on the lake ice, 10 water layers, and 10 soil layers on the lake bottom (see the WRF User's Guide Chapter 5, Section 3.4 http: / www2.mmm.ucar.edu/ wrf/users/docs/user_guide_V3/users_guide_chap5.htm). The lake scheme has been performed with actual lake points and lake depth derived from the WRF Preprocessing System (WPS). The lake scheme is independent of a land surface scheme and therefore can be used with any land surface scheme embedded in WRF.

In the default lake model, the albedos of water and ice are specified with constant values, 0.08 and 0.6, respectively, ignoring solar diffusion, radiation spectrum, and snow effect. Before the implementation of the coupled WRF-Lake model, some modifications have been added to the lake model, including a dynamic lake surface albedo, calibrated vertical diffusivities, and a sophisticated treatment of snow cover over lake ice [45]. At the current grid spacing, the Great Lakes are well represented in our WRF-Lake model (Fig. 3).

\subsection{Experimental design}

A set of variables from the GFDL-CM3 archive was prepared into 6-hourly input to drive WRF (Table 3). The 3-D fields (ta, ua, va, hus) and surface fields (tas, uas, vas, huss) were directly obtained from the 6-hourly CMIP5 output. Geopotential height (zg) was computed using the hydrostatic equation. Two downscaling experiments have been conducted: historical simulation (1970-2005, denoted as HIS) and future projection (2006-2100) in the Representative Concentration Pathway 4.5 scenario (RCP), a midrange mitigation emissions scenario. Each experiment was allowed a 4-5 year spin-up time. The analyzed periods in HIS and RCP are 1975-2005 and 2010-2100, respectively. 
Table 3. Variables of the standard CMIP5 output used to drive WRF 6-houly ta (tas), ua (uas), va (vas), and hus (hus) provide 3-dimentional (surface) air temperature, zonal wind, meridional wind and specific humidity. 6-houly ps and psl are surface pressure and mean sea level pressure. Geopotential height (zg) is calculated using the hydrostatic equation. Monthly surface temperature (ts) on the ocean grids is interpolated into 6-hourly SST. Monthly soil temperature (tsl) is also interpolated into 6-hourly tsl.

\begin{tabular}{ccccc}
\hline Layer & 3D & Surface & SST & Soil \\
\hline Variables & ta, ua, va, hus, zg & tas, uas, vas, huss, ps, psl & ts & tsl \\
\hline
\end{tabular}

\subsection{Additional datasets}

For validation of the historical simulation, simulated air temperature and precipitation from WRF were assessed against two reanalysis datasets, the National Centers for Environmental Prediction/National Center for Atmospheric Research (NCEP/NCAR) on a 2.5-degree grid [46] and NCEP North American Regional Reanalysis (NARR) on a $32 \mathrm{~km}$ spatial resolution. In addition to the reanalysis, a precipitation dataset was also used for the historical validation: the Global Precipitation Climatology Project (GPCP) version 2.2 on a 2.5-degree global grid [47].

The simulated LST from the 1-D lake model was compared with the National Oceanic and Atmospheric Administration (NOAA) Great Lakes Surface Environmental Analysis (GLSEA) dataset from the Advanced Very High Resolution Radiometer [48]. NOAA's Great Lakes Ice Atlas [8] was applied to evaluate the simulated seasonal cycle of lake ice.

\section{Result}

\subsection{Validation of historical simulation}

WRF was used as an RCM to dynamically downscale from reanalysis $[49,50]$ and GCMs $[27,51$, 52]. In the Great Lakes area, WRF has been proven to be a powerful tool to study lake influences $[11,27,32,53]$. One thing to be noted is that, even in the historical experiment with real greenhouse gas and other historical forcing, GCMs might generate a climate phase that is quite different from the real observation [54]. The RCM and GCM results cannot be directly assessed against reanalysis datasets year by year, while their long-term climatology is comparable. To evaluate the coupled WRF-Lake model's performance in the downscaling, the historical climatology (1975-2005) of 2-meter air temperature (T2) was compared with GFDL-CM3, CMIP5 MME, and two reanalysis datasets.

The annual, winter (December-January-February), and summer (June-July-August) climatologies of T2 are shown in Fig. 4. The contours of annual mean T2 in GFDL-CM3 and MME are quasi-zonal, indicating the Great Lakes region was treated as a unified land surface in GCMs. With a fine resolution and well-represented lakes, some local characteristics that were missed in GCMs and NCEP/NCAR are reproduced in the WRF simulation, compared to the high-resolution NARR. Because of the heating from lakes in winter, the air temperature over Lake Superior and Lake Michigan is warmer than the surrounding land area at the same latitude, and vice versa in summer. Lake Erie acts as a warming pool to the overlying atmosphere in the summer. Some discrepancies also exist in the WRF-Lake model. There is a systematic cold bias in the RCM, which was partially induced by the parent GCM. The lake model magnified the cooling effect from lakes, especially in summer time. 
(a)WRF_Annual
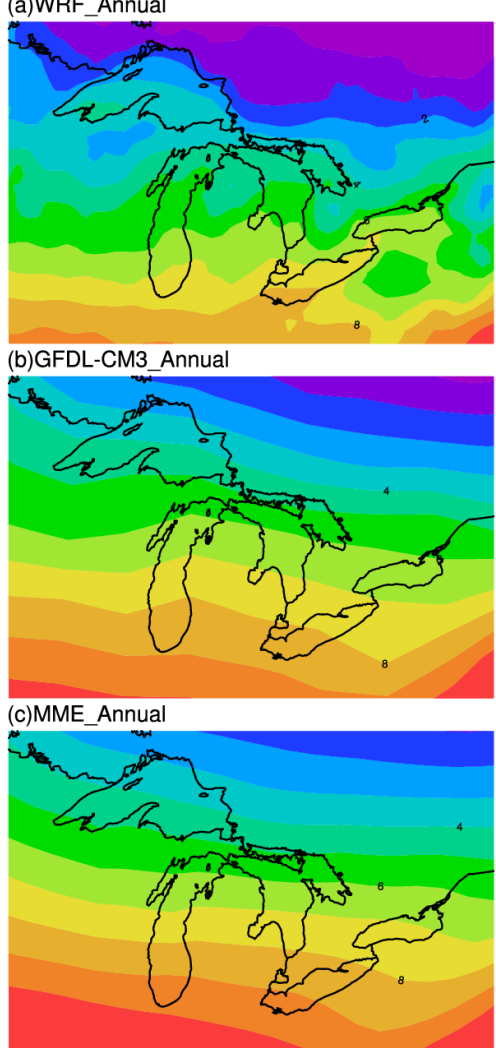

(d)NCEP/NCAR_Annual

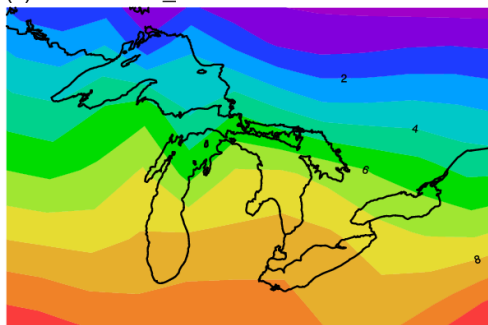

(e)NARR_Annual
(f)WRF_Winter
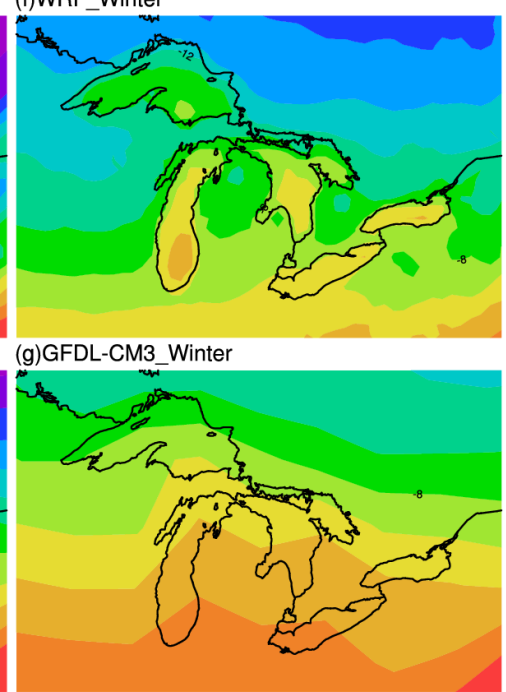

(h)MME_Winter

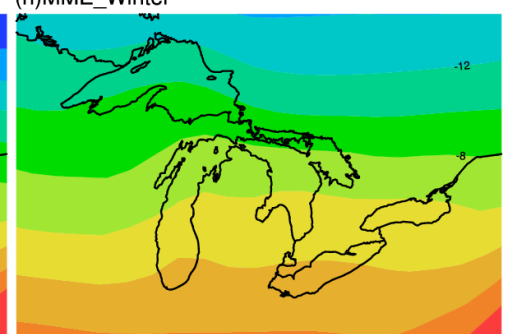

(i)NCEP/NCAR_Winter

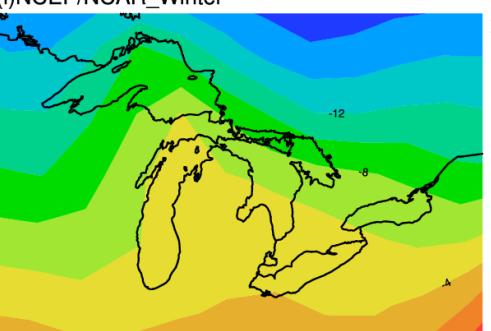

(j)NARR_Winter
(k)WRF_Summer

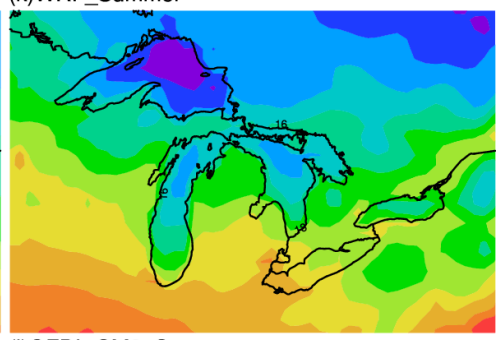

(I)GFDL-CM3_Summer

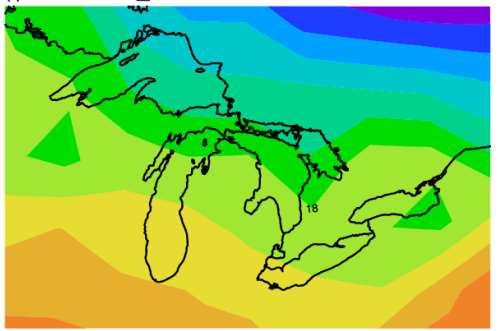

(m)MME_Summer

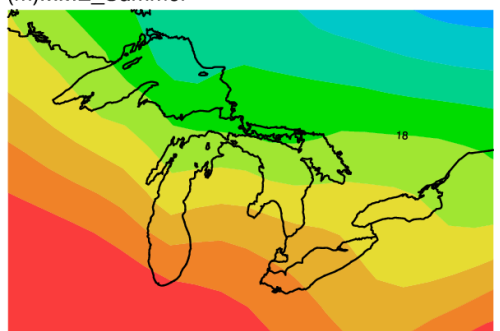

(n)NCEP/NCAR_Summer

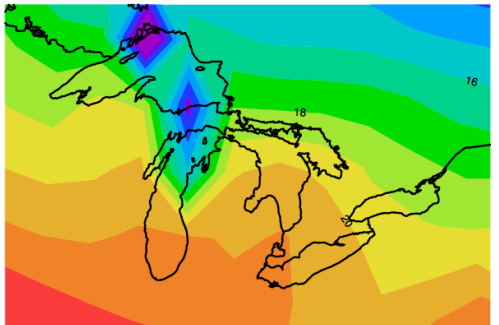

(o)NARR_Summer
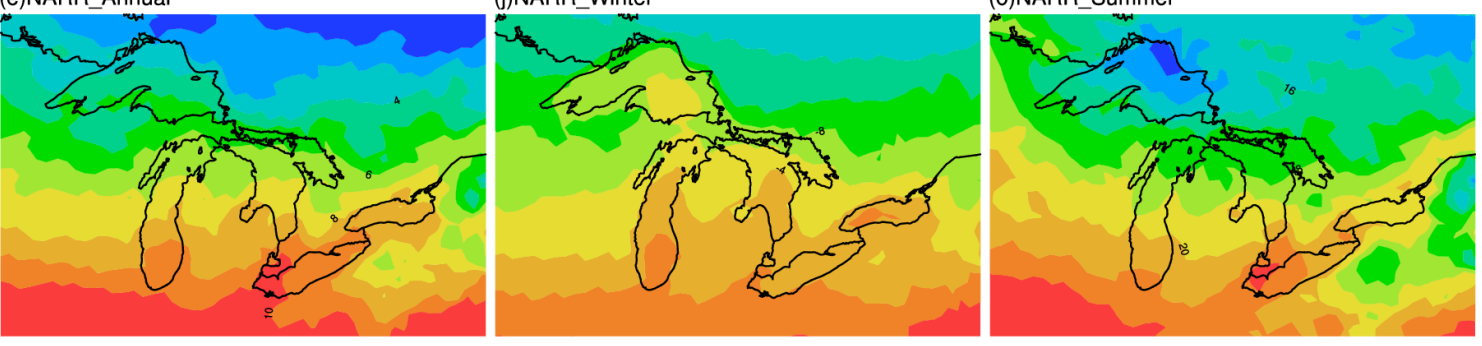

2

Figure 4. Left panels are the annual mean air temperature $\left({ }^{\circ} \mathrm{C}\right)$ in WRF, GFDL-CM3, MME, NCEP/NCAR, and NARR. Central panels are in winter, and right panels are in summer.

In addition to air temperature, precipitation from the RCM and GCMs is also assessed against observations (Fig. 5). In winter, the general pattern (southeast-northwest gradient) of precipitation has been reproduced by both GCMs and RCM. The lake effect in winter, i.e. strong precipitation along the downwind shores of the lakes, was well captured by WRF. In summer, the spatial pattern of precipitation is characterized by more rainfall occurring over land than over lake [55]. Compared to T2, the precipitation has a larger diversity among RCM, GCMs, reanalysis and the satellite-based observation, especially in summer. A shortcoming of our WRF simulation is that the overland precipitation in summer was overestimated, which was also found in Gula and Peltier [27]. We 
further examined the vapor source (not shown). After the lakes were introduced in the RCM, opposite to the GCM without resolved lakes, the evaporation from the lakes increased the total precipitable water in the domain, resulting in some extra rainfall in the area surrounding the lakes. Compared to the wintertime precipitation which is dominated by the grid-scale convection, the discrepancy of summertime rainfall may arise from the uncertainty of the cumulus parameterization (e.g. Yang et al. [56]). Our downscaling result is quite consistent with the observations that less precipitation was produced over lake than over land in summer.

It has been demonstrated that the MME is able to reduce model uncertainties and agrees better with observations than a single model [57]. However, if there is a systematic discrepancy, such as no lakes being represented, in CMIP5 models, the MME result doesn't change the overall shortcoming. This discrepancy even exists in the reanalysis data when it is too coarse to resolve individual lakes. On this point, the downscaling technique becomes particularly important to mitigate this problem. The above assessment of T2 and precipitation indicates that the historical simulation from GFDL-CM3 has been significantly improved by the WRF downscaling which is coupled with a lake model. In the following subsections, we will analyze the future projection in our WRF-Lake model and compare it with GFDL-CM3 and CMIP5 MME.

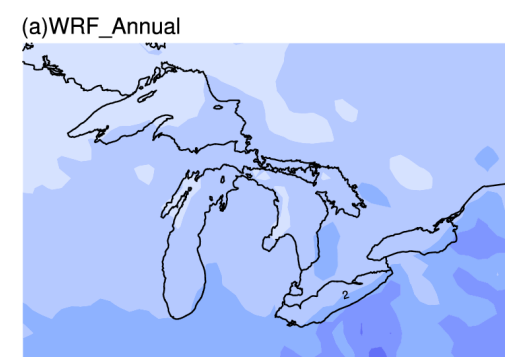

(b)GFDL-CM3_Annual

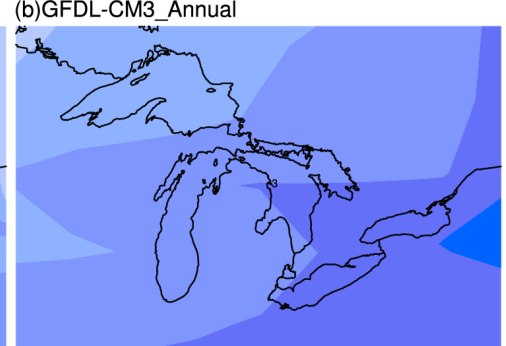

(c)MME_Annual
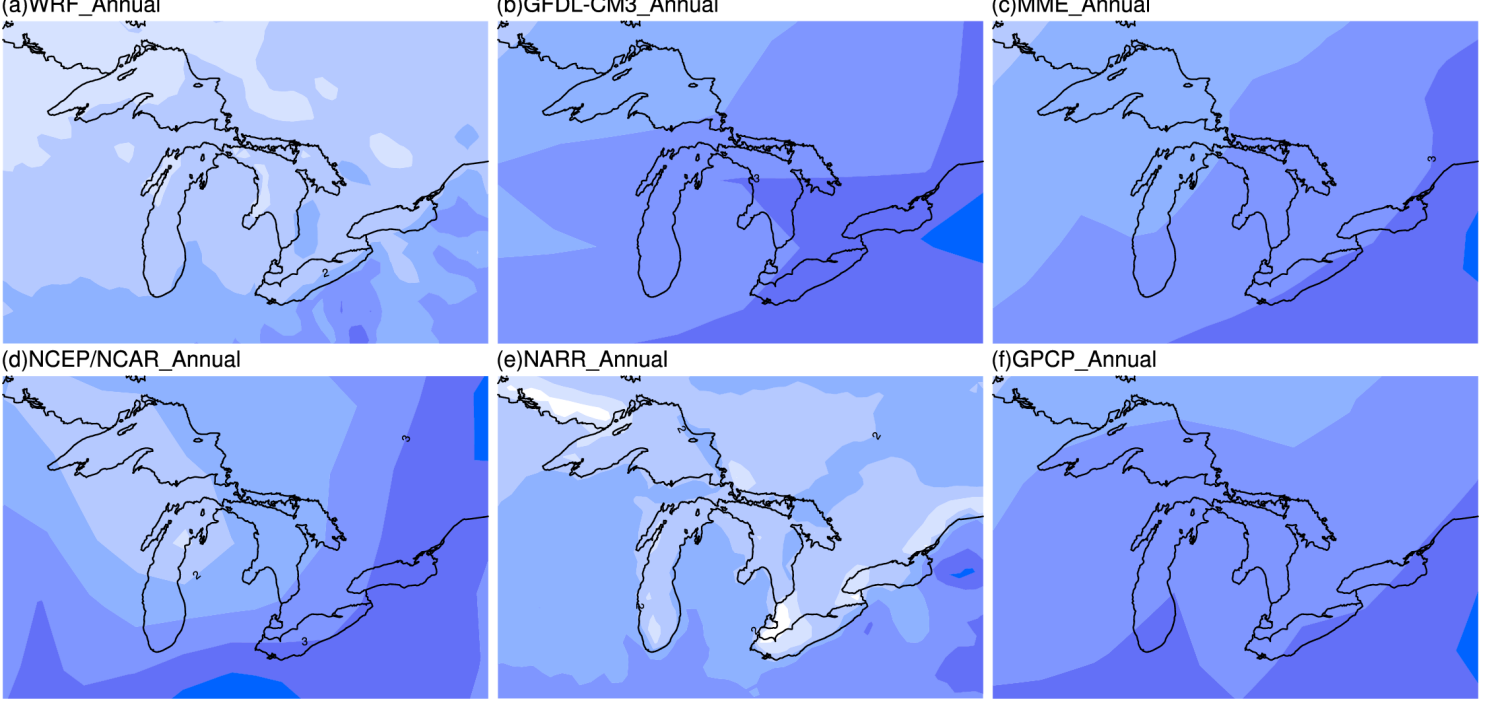

(e)NARR Annual
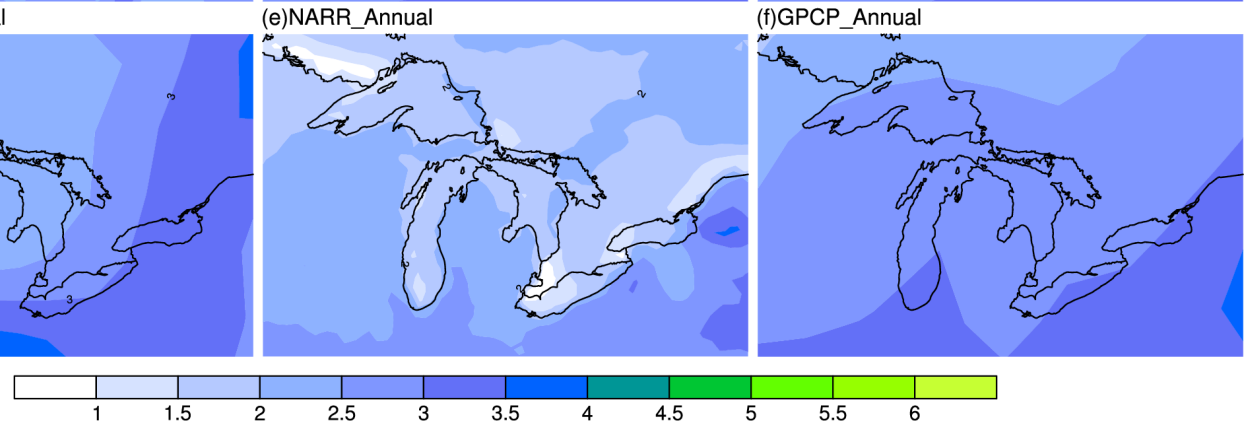

Figure 5. Annual mean precipitation (mm/day) in WRF, GFDL-CM3 and MME, compared with NCEP/NCAR, NARR, and GPCP.

\subsection{Future projection: climatology}

Fig. 6 illustrates the projected change of T2 climatology, RCP (2070-2100) minus HIS (1975-2005), in WRF, GFDL-CM3 and MME. In the GCM, annual mean T2 was projected to rise more than $3{ }^{\circ} \mathrm{C}$ above the historical level, with the greatest warming occurring in the Hudson Bay region, which was also evidenced in MME but with a reduced magnitude. The WRF downscaling result is quite similar to the GCM in both the spatial pattern and intensity. In winter, a strong temperature gradient, slight cooling in the southwest and strong warming in the northeast, was projected in both GFDL-CM3 and WRF. The main difference was in the Great Lakes region where the wintertime T2 was projected to have a larger increase in the RCM than that in the GCM, especially in Lake Superior where the overlaying atmosphere could be warmed as much as $5^{\circ} \mathrm{C}$ after the lake was introduced in WRF. The future change of the summertime $\mathrm{T} 2$ was characterized with a domain-wide strong warming in GFDL-CM3 and WRF, but the magnitude was reduced in WRF, agreeing with the MME's projection. In the downscaling procedure, the WRF didn't alter the overall pattern of T2 change projected by 
GFDL-CM3, but highlighted the Great Lakes' influence on the atmosphere at local and regional scales, which was missed in CMIP5 GCMs.

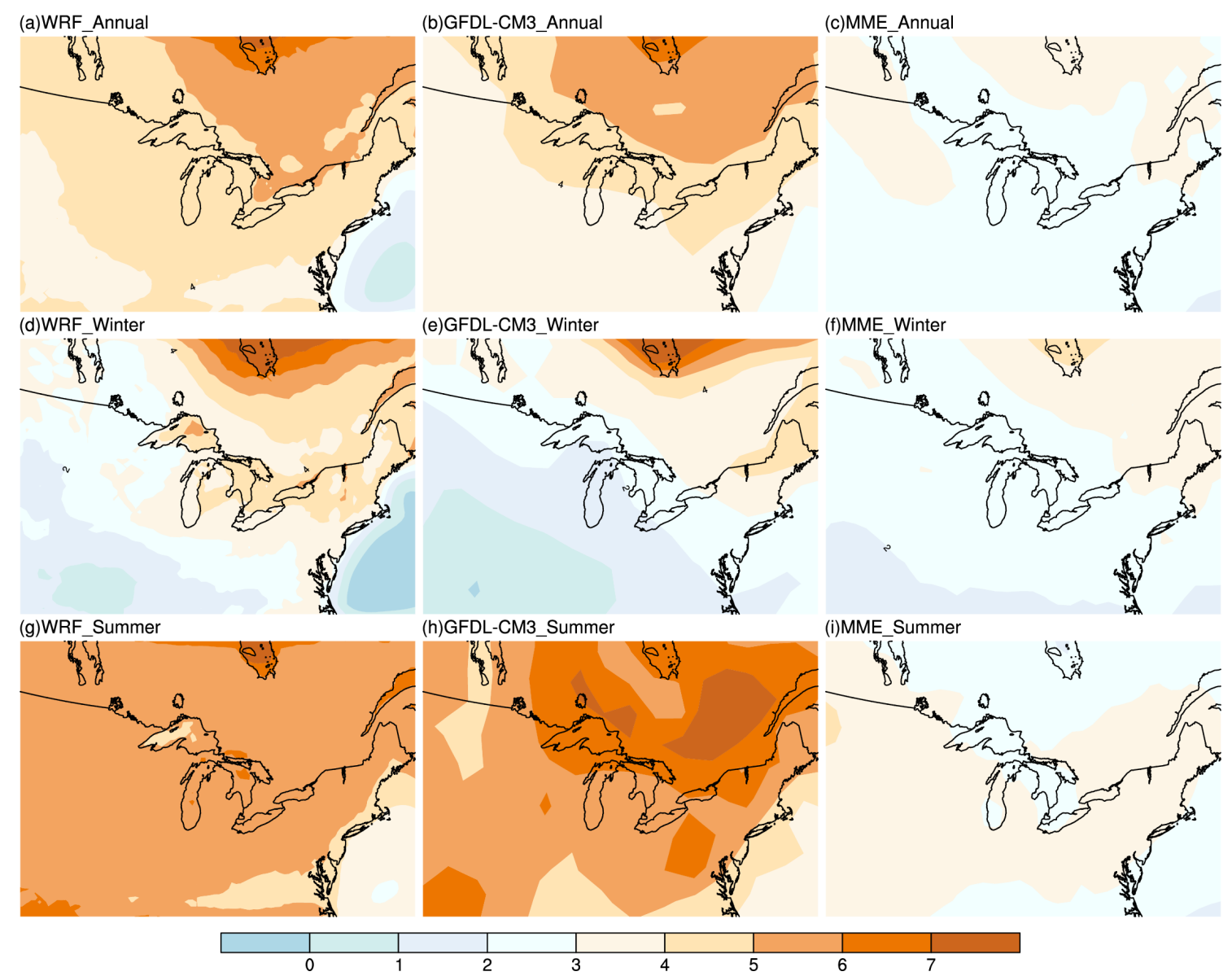

Figure 6. Projected change (RCP-HIS) of air temperature $\left({ }^{\circ} \mathrm{C}\right)$ between future projection (RCP, 2070-2100 average) and historical simulation (HIS, 1975-2005 average) in annual mean by (a) WRF, (b) GFDL-CM3, and (c) MME. (d), (e), and (f) in February. (g), (h), and (i) in August.

According to the Clausius-Clapeyron expression, the saturation vapor pressure is regulated by the air temperature. The column-integrated water vapor increases by roughly $7.5 \% \mathrm{~K}^{-1}$, and precipitation by $2.2 \% \mathrm{~K}^{-1}$ [58]. The local precipitation change, which can be attributed to multiple factors: water vapor, instability, and topography, exhibits a strong spatial heterogeneity (Fig. 7), relative to the air temperature change (Fig. 6). In the annual mean precipitation, the region southeast of the Great Lakes was projected to have more precipitation in a warming climate by GFDL-CM3 (Fig. $7 \mathrm{~b})$, while WRF added more precipitation in the southwest and northeast land areas. In winter, the RCM-based projection of precipitation was in agreement with the GCM, with particular enhancement of precipitation just downwind of Lakes Superior, Huron, and Ontario. In a warming climate, more precipitation is likely to happen to the southeast side of the Great Lake region in winter. A striking disparity between the RCM and the GCM occurs in summer. Less rainfall was projected by WRF (Fig. $7 \mathrm{~g}$ ), especially in the lower lakes, while GFDL-CM3 projected more rainfall in the Great Lakes (Fig. 7h). Our WRF/GFDL-CM3 downscaling result is consistent with another studies using a different RCM and GCM, RegCM4/MIROC5 (Fig. 9 in Notaro et al. [29]), implying that the summertime precipitation in the Great Lakes tends to be declining under Global warming in the future. In MME, very small precipitation changes were projected in the Great Lakes region, indicating a large spread of precipitation among CMIP5 models. 


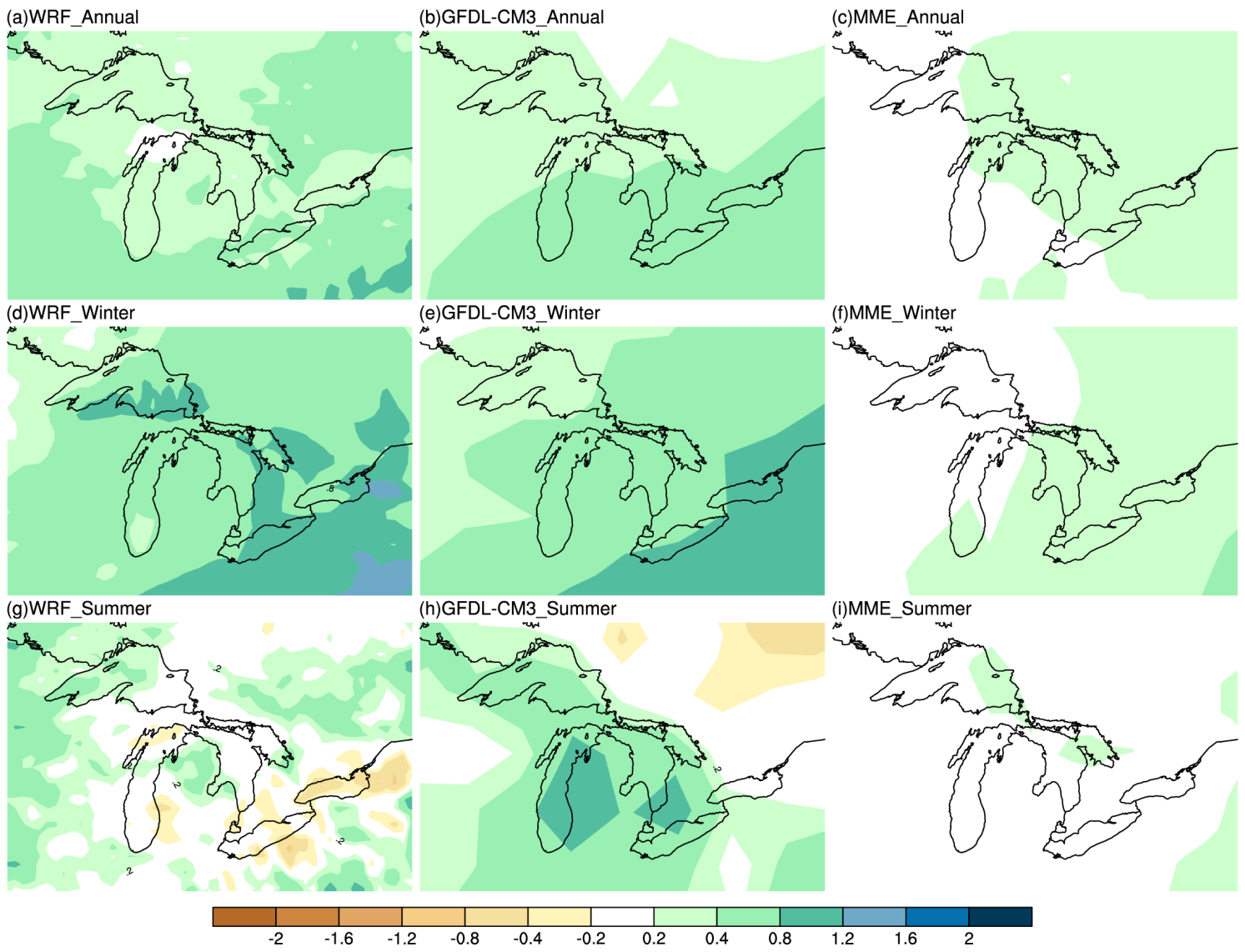

Figure 7. Same as Fig. 6 but for precipitation (mm/day).

\subsection{Future projection: trends}

In the previous two subsections, we compared the climatology of historical simulation and future projection. In this subsection, their interannual variabilities and trends will be examined. Fig. 8 shows the area-mean T2 in HIS and RCP simulated by WRF, GFDL-CM3 and MME. In both HIS and RCP, the RCM has maintained the intraseasonal and interannual variabilities that were produced by the GCM. The difference between RCP and HIS (Figs. 8c and 8f) suggests that even in a much warmed climate in the late 21st century we will still experience some cold winters. In CMIP5 MME with interannual variability smoothed by averaging over many model runs, a ubiquitous warming (about $2-4{ }^{\circ} \mathrm{C}$ ) was projected all year round.

Because of the large heat capacity of water bodies, the Great Lakes can significantly modulate the seasonal variability of the overlaying atmosphere, even the long term trend. The time series of T2 over each lake during the entire projection period from 2010 to 2100 are compared in Fig. 9. CMIP5 GCMs have projected a noticeable spread of T2 over the Great Lakes. The inter-model spread becomes larger in winter than summer. GFDL-CM3 generally projected a warm climate, with sensitivity ranking in the middle of the CMIP5's projection. The comparison between annual mean T2 in GFDL-CM3 and MME manifests that the GCM which we selected to drive the RCM is somewhat typical of the CMIP5 ensemble. After the lakes were present in a higher-resolution model, the seasonal variability of T2 was reduced in WRF with cooler summers and warmer winters relative to GFDL-CM3. Projected trends of T2 in WRF, GFDL-CM3 and MME were calculated (Table 4). In the RCP4.5 scenario, the T2 will have a rapid increase in the first half-century and the rate of increase will slow down gradually in the second half Taylor et al. [36]. A relatively strong T2 trend was projected by GFDL-CM3 in the Great Lakes region. The WRF model projected a similar trend but modulated the magnitude by increasing (reducing) the trend in winter (summer), compared to the MME result. 

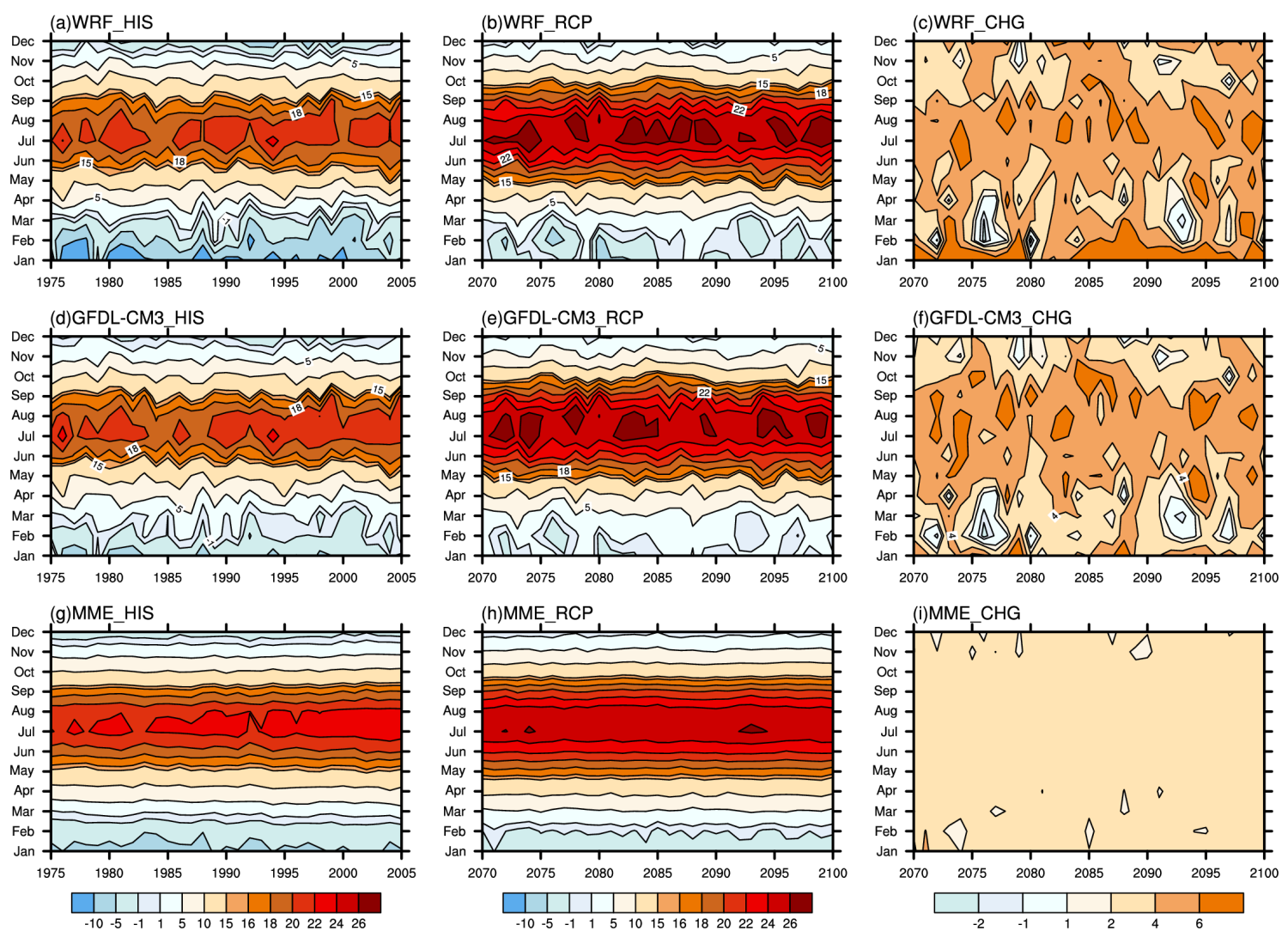

Figure 8. (a) Historical simulation (HIS), (b) future projection (RCP), (c) and the change (CHG=RCP-HIS climatology) of air temperature $\left({ }^{\circ} \mathrm{C}\right)$ in WRF. (d), (e), and (f) in GFDL-CM3.(g), (h), and (i) in MME.

Table 4. Projected air temperature trends $\left({ }^{\circ} \mathrm{C} / 100\right.$ year) in WRF, GFDL-CM3 and MME for the $1^{\text {st }}$ half century (2010-2055), the $2^{\text {nd }}$ half century (1955-2100), and then entire century (2010-2100)

\begin{tabular}{cccccccccc}
\hline Trends & \multicolumn{3}{c}{ WRF } & \multicolumn{3}{c}{ GFDL-CM3 } & \multicolumn{3}{c}{ MME } \\
\hline & $1^{\text {st }}$ half & $2^{\text {nd }}$ half & Cent. & $1^{\text {st }}$ half & $2^{\text {nd }}$ half & Cent. & $1^{\text {st }}$ half & $2^{\text {nd }}$ half & Cent. \\
Feb. & 8.8 & 0.3 & 4.1 & 6.7 & -0.2 & 3.1 & 4.9 & 1.6 & 3.5 \\
Aug. & 6.5 & 1.8 & 4.7 & 8.0 & 3.4 & 6.0 & 3.8 & 0.8 & 2.8 \\
Annual & 6.7 & 1.2 & 4.5 & 6.8 & 0.9 & 4.5 & 4.0 & 1.2 & 2.8 \\
\hline
\end{tabular}

\subsection{Future projection: seasonality}

Large water bodies such as the Great Lakes can diminish the seasonal variability of air temperature [5]. To study the response of the Great Lakes' modulation of air temperature to global warming, the seasonal evolutions of T2 over each lake are compared in Fig. 10. In the historical simulation, the summertime T2 was reduced in WRF and this effect became more significant in the deep lakes (Superior, Michigan and Huron) than the shallow lakes (Erie and Ontario). In all season other than spring, GFDL-CM3 simulated a historical climate near the middle of the distribution of CMIP5 models. Generally, the projection for the GCM we selected ranks in the middle among the CMIP5 models, suggesting that our downscaling results are representative. The GCM projected a stronger warming of T2 in summer than in winter over all lakes, especially Lake Superior. The lakes' impact on T2 is projected to be enhanced in the future. For example, T2 was projected to warm by $6.7^{\circ} \mathrm{C}$ on Lake Superior in March by GFDL-CM3 differing sharply from the $3.0^{\circ} \mathrm{C}$ warming in WRF. MME generally projected a smaller increase in $\mathrm{T} 2$ which was almost unified among all months. In January and February, because too much ice was produced in the lake model (to be elaborated in section 3f), an 
even colder T2 was simulated in WRF relative to GFDL-CM3 in the historical simulation, while this discrepancy was almost eliminated in the future projection when ice was reduced.
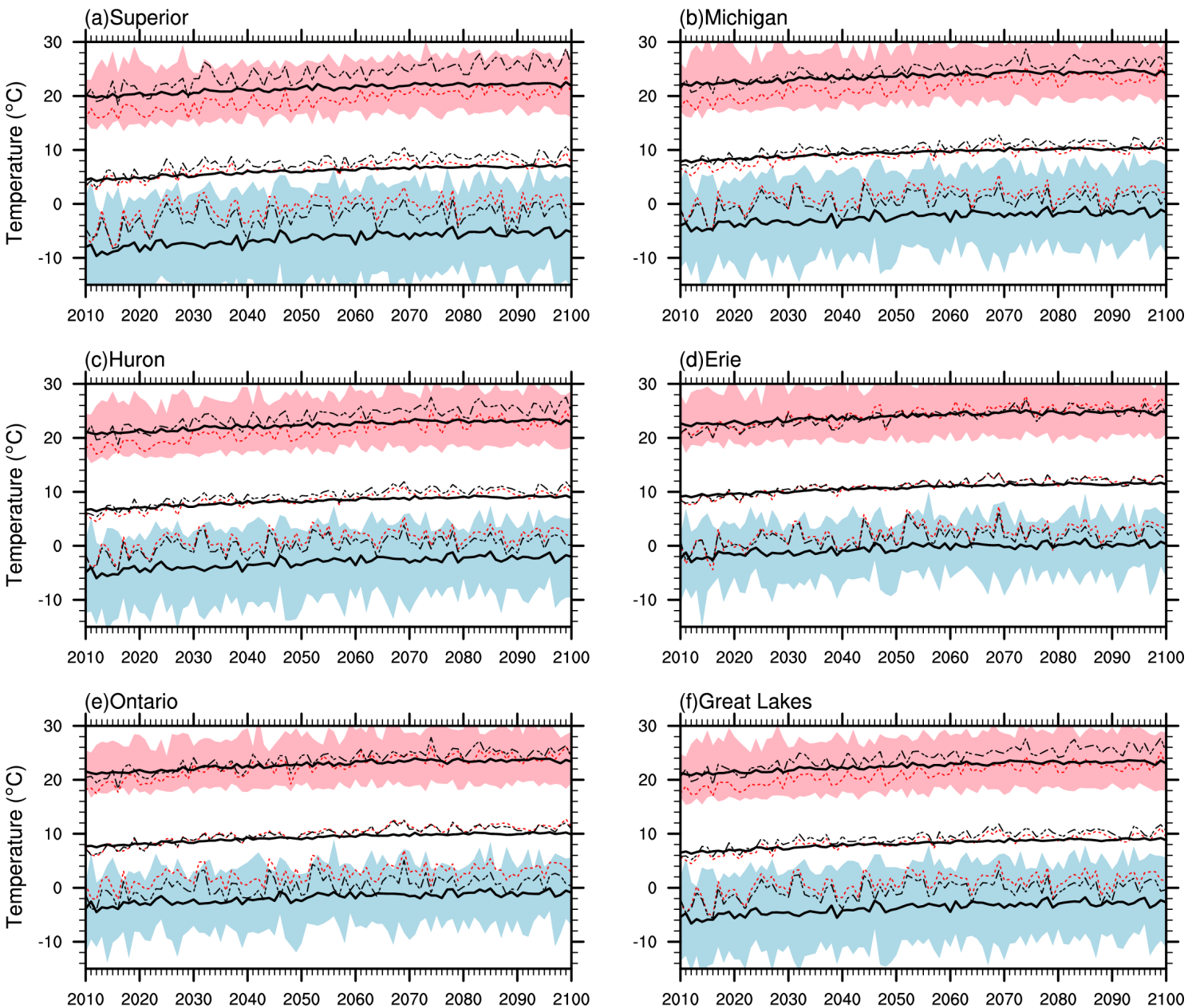

Figure 9. (a) Projected T2 $\left({ }^{\circ} \mathrm{C}\right)$ over Lake Superior in August, annual mean and February by WRF (red dash), GFDL-CM3 (black dash), MME (solid). The shading (red in August and blue in February) denotes the range of T2 among CMIP5 models. (b), (c), (d), (e), and (f) are same as (a),but for Lake Michigan, Lake Huron, Lake Erie, Lake Ontario, and the Great Lakes, respectively.

The above analysis from the atmospheric component of the coupled WRF-Lake model indicates that an RCM at a higher resolution can not only improve the GCM's result but also add values, such as lake effects on precipitation and air temperature, after a sophisticated lake model was incorporated in the RCM. In next two subsections, the result from the lake component will be evaluated in terms of LST and lake ice coverage which cannot be obtained from the GCM. 
(a)Superior_HIS

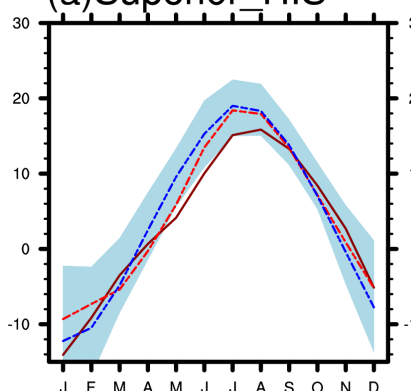

(f)Superior RCP

(k)Superior_Change

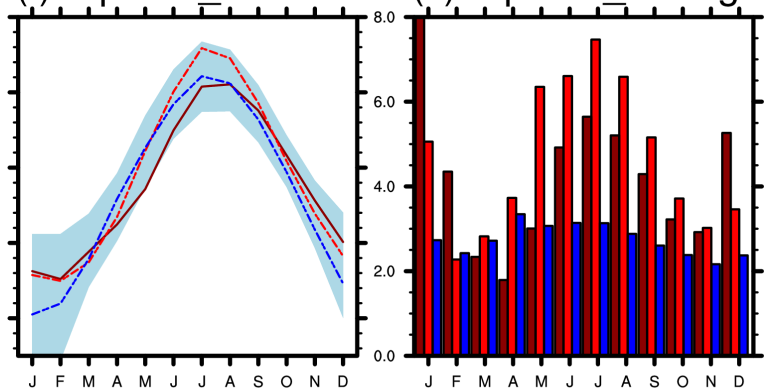

(b)Michigan_HIS

(g)Michigan_RCP

(I)Michigan_Change
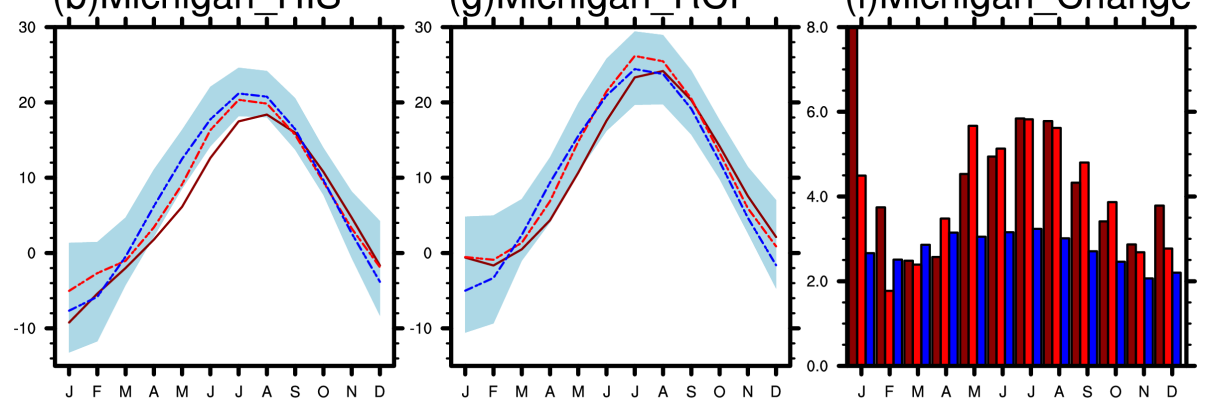

(c)Huron_HIS

(h)Huron RCP

(m)Huron Change
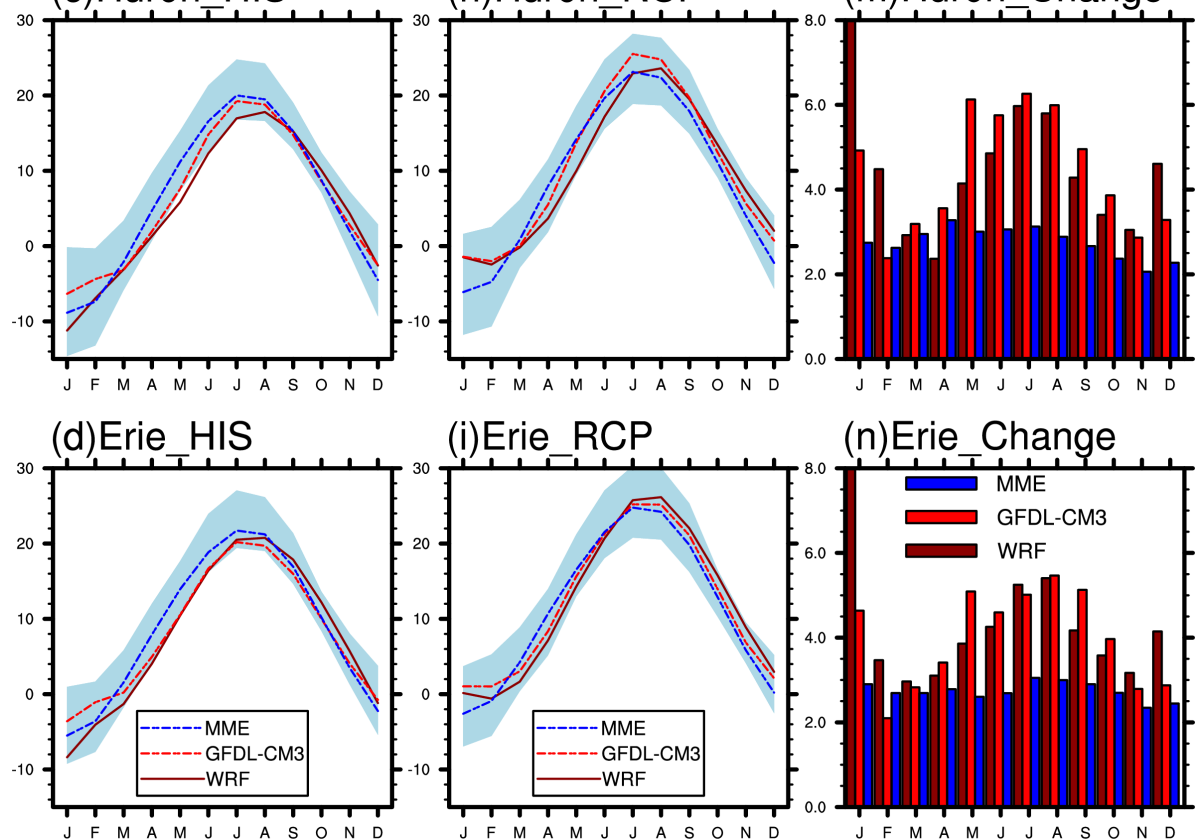

(i)Erie RCP

(n)Erie Change
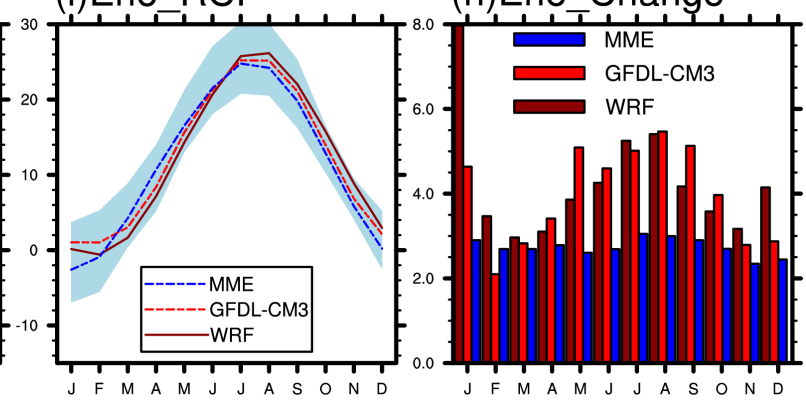

(e)Ontario HIS

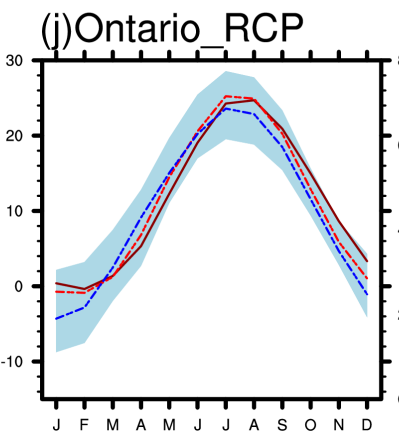

(o)Ontario Change
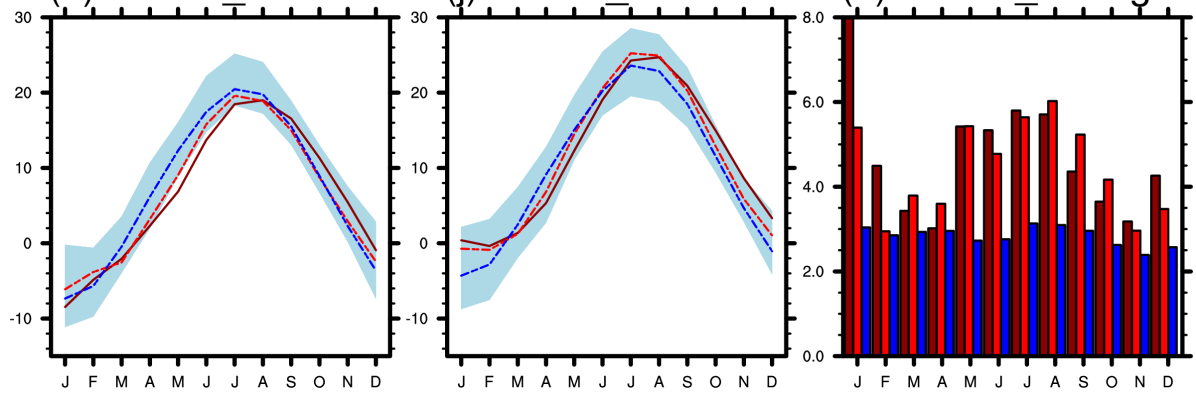

Figure 10. (a) Historical simulation (HIS, 1975-2005 average), (f) future projection (RCP, 2070-2100 average), and (k) their difference (RCP-HIS) of T2 $\left({ }^{\circ} \mathrm{C}\right)$ seasonality in Lake Superior by WRF (red solid), GFDL-CM3 (red dash), MME (blue dash). The blue shading denotes the range of T2 among CMIP5 models. 

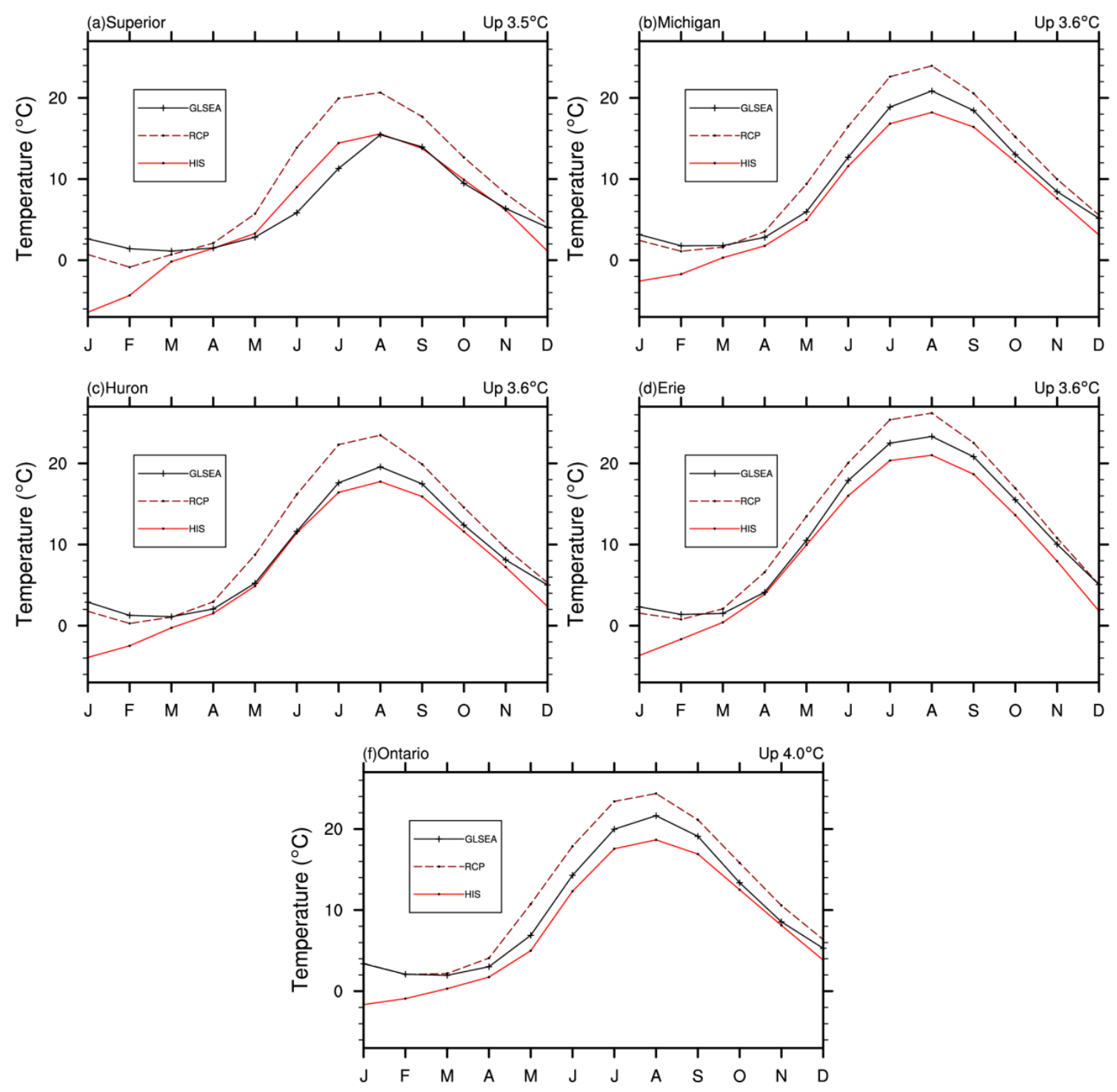

Figure 11. Historical simulation (HIS, red solid) and future projection (RCP, red dashed) of LST $\left({ }^{\circ} \mathrm{C}\right)$ by WRF, compared with GLSEA observation (black) in (a) Lake Superior, (b) Lake Michigan, (c) Lake Huron, (d) Lake Erie, and (f) Lake Ontario.

\subsection{Lake model: temperature}

The current lake model employed 10 vertical layers in the Great Lakes. The top layer was set at a constant depth $(0.05 \mathrm{~m})$ and the layers below were scaled to the lake bathymetry. Fig. 11 depicts the monthly climatology of the simulated and projected LST in each lake compared with the GLSEA observation, with caution if ice is formed in winter that the LST in the 1-D lake model represents the mean temperature of water and ice in the top layer. Since there was no lake information in the GCM, the GCM-based simulation cannot be directly compared to the satellite-based observation. The downscaling result had a systematically cooler LST than GLSEA, except for Lake Superior, which is the coldest lake. However, the seasonal variability of LST has been well reproduced by the 1-D lake model. In the RCP4.5 scenario, LST was projected to increase by roughly $3.5^{\circ} \mathrm{C}$ in Lake Superior and up to $4.0^{\circ} \mathrm{C}$ in Lake Ontario. Similar to T2 (Fig. 10), LST will rise more in summer than winter. The magnitude of the LST change is smaller than that of the T2 change. 

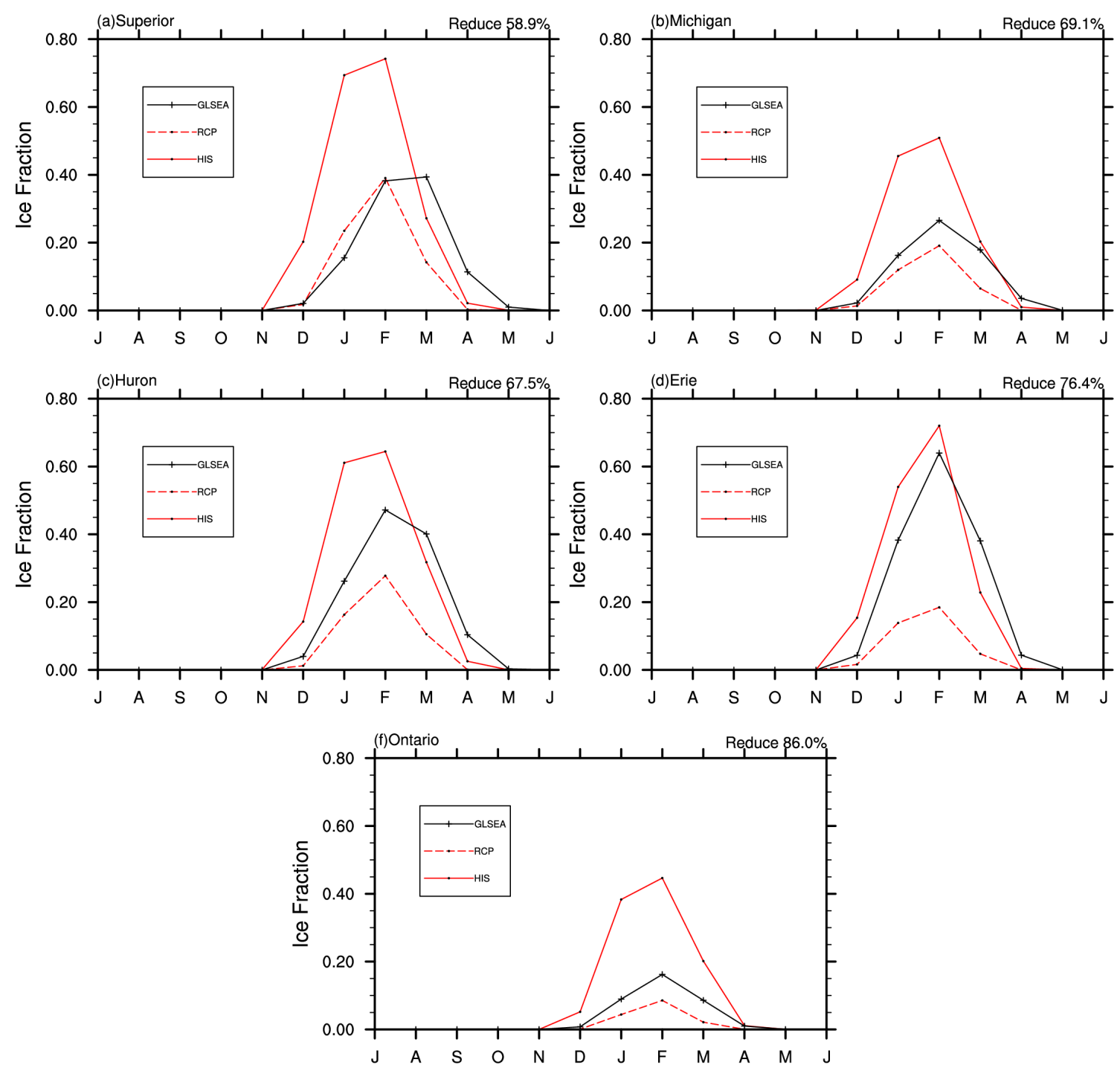

Figure 12. Same as Fig. 10, but for ice coverage fraction.

\subsection{Lake model: ice}

With a large interannual variability, the ice coverage is a sensitive indicator of regional climate and climate change (Wang et al. 2012). Because of the difference of latitude, orientation, and depth of each lake, the ice cover in the Great Lakes exhibits distinct spatial and temporal variabilities. Simulating the lake ice tends to be a considerable challenge in current RCM-lake models $[5,25,27]$. The simulated and projected monthly ice coverage in each lake is compared to the observation in Fig. 12. In part because of the absence of horizontal mixing and ice motion in the 1-D lake model, the WRF-Lake model produced early ice onset and excessive mid-winter ice. The overall cold LST (Fig. 11) can also contribute to the overestimate of lake ice in the lake model. With the LST increasing by $3.5-4{ }^{\circ} \mathrm{C}$, the ice coverage was projected to decrease by $58.9 \%$ (Lake Superior) to $86 \%$ (Lake Ontario). Given that the ice coverage in the historical simulation was substantially overestimated, the future change of ice coverage is likely to be amplified by the lake model. In addition to the lake-mean ice coverage, the seasonal change of the spatial ice coverage was further examined (Fig. 13). Heavy ice was produced in north coastal Lake Superior. The lower lakes will experience more dramatic ice losses under global warming. In April in the last decades of 21 century, the ice will almost disappear in all lakes. 


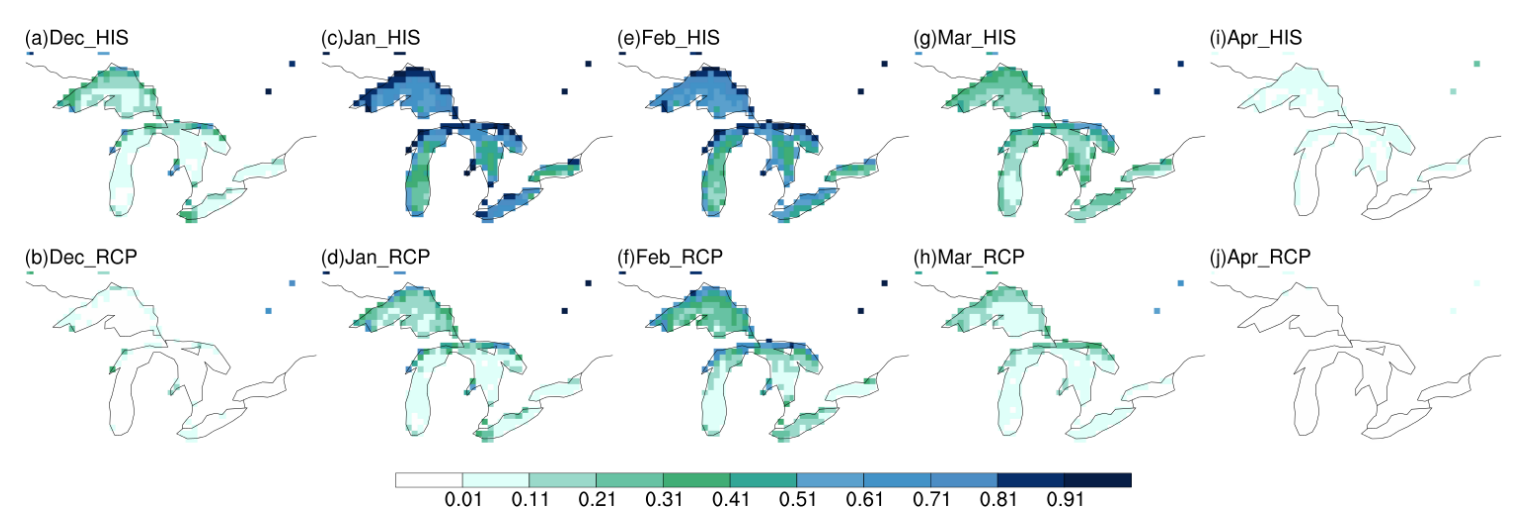

Figure 13. (a) Historical simulation and (b) future projection of ice coverage fraction in December. (c) and (d) in January; (e) and (f) in February; (g) and (h) in March; (i) and (j) in April.

\section{Conclusions and discussion}

A dynamical downscaling study has been carried out in the Great Lakes region employing a state-of-the-art RCM driven by the CMIP5 output from GFDL-CM3. Compared to prior downscaling studies (Table 1), our work is highlighted by using a nonhydrostatic WRF model with a fully coupled lake model to conduct two consecutive experiments: historical simulation from 1970 to 2005 and future simulation from 2006 to 2100. The influence of the Great Lakes on local and regional climate was evaluated against 24 CMIP5 models and multiple observational datasets. The major conclusions can be synthesized as follows:

1. Because of the coarse resolution in GCMs, the Great Lakes are generally ignored by CMIP5 models. It becomes particularly necessary to apply an RCM with resolved lakes to downscale from GCMs in the water-dominated region. GFDL-CM3 is shown to be a credible representative of CMIP5 models to be downscaled.

2. Validations of historical simulation indicate that, compared to GCMs at coarse resolution and without lakes represented, the WRF-Lake model with 30-km grid spacing and well-resolved lakes is capable of reproducing a more reasonable spatial-temporal climatology in the Great Lake region, as well as the lake-induced characteristics that were missed in the GCMs.

3. With lakes present, the seasonal variability and future change of air temperature were reduced in the WRF-Lake model, especially in summer. Even in an overall warming climate, we could still experience some colder-than-20th-century winters in the late 21st century.

4. In the RCP4.5 scenario, air temperature will have a rapid increase in the first half-century and the rate of increase will slow down gradually in the second half. The air temperature trend is reduced in the WRF-Lake model, to about $4.5^{\circ} \mathrm{C} / 100$ year.

5. The RCM-based projection indicates a possible decline of over-lake precipitation under global warming in summer.

6. The seasonal variability of lake surface temperature and lake ice coverage was captured by the 1-D lake model. The WRF-Lake model projected rise in a temperature $\left(3.5-4{ }^{\circ} \mathrm{C}\right)$ and ice loss $(58.9 \%-86 \%)$ in the Great Lakes.

Even though substantial improvements have been demonstrated in our downscaling study, the present work cannot disguise its limitation to understanding the regional impact of the Great Lakes under global climate change. The limitation comes from several aspects in the downscaling technique. (1) Our study is based on a single scenario from a single GCM, while the comparison of multiple CMIP5 models will better illuminate the WRF-Lake results and their uncertainty. (2) The RCM's performance is very sensitive to physical parameterizations, which can be optimized in future work. (3) The inadequacy of the 1-D lake model produces too much ice at deep lake points. Future efforts should be devoted to improving the downscaling technique in the Great Lakes region: an improved parameterization in RCM, possibly coupled with 3-D lake model, to generate multiple downscaling 
ensembles not only from different CMIP5 models but also from different greenhouse gas concentration scenarios.

As revealed in the observation that the lake surface waters around the globe have been experiencing a rapid warming $[59,60]$, the future projection of lake temperature rising and lake ice diminishing in this study have important implications for applying anthropogenic climate change onto a regional scale, such as lake-influenced regions.

Author Contributions: C.X. performed the numerical experiments, data analysis and manuscript preparation. B. M. L. motivated the study and guided the process analysis. J. W. and P. Y. C. contributed to the analyses and manuscript.

Acknowledgments: The authors acknowledge the NOAA Research and Development High Performance Computing Program for providing computing and storage resources that have contributed to the research results reported within this paper (http:/ /rdhpcs.noaa.gov). Special thanks to Nicole Rice at NOAA/GLERL for editing this paper. This research is funded by the US Environmental Protection Agency's Great Lakes Restoration Initiative (GLRI). Figures are created with the NCAR Command Language (Version 6.1.2) [Software]. [2014]. Boulder, Colorado: UCAR/NCAR/CISL/VETS. http:/ / dx.doi.org/10.5065/D6WD3XH5. Funding was awarded to Cooperative Institute for Great Lakes Research (CIGLR) through the NOAA Cooperative Agreement with the University of Michigan (NA17OAR4320152). All data and codes in this paper are available upon request. This is CIGLR contribution \#\#\#.

Conflicts of Interest: The authors declare no conflict of interest.

1. Changnon, S.A.; Jones, D.M.A. Review of the influences of the Great Lakes on weather. Water Resources Research 1972, 8, 360-371.

2. Bates, G.T.; Giorgi, F.; Hostetler, S.W. Toward the Simulation of the Effects of the Great-Lakes on Regional Climate. Monthly Weather Review 1993, 121, 1373-1387.

3. Scott, R.W.; Huff, F.A. Impacts of the Great Lakes on regional climate conditions. Journal of Great Lakes Research 1996, 22, 845-863.

4. Lofgren, B.M. Simulated effects of idealized Laurentian Great Lakes on regional and large-scale climate. Journal of Climate 1997, 10, 2847-2858.

5. Notaro, M.; Holman, K.; Zarrin, A.; Fluck, E.; Vavrus, S.; Bennington, V. Influence of the Laurentian Great Lakes on Regional Climate. Journal of Climate 2013, 26, 789-804.

6. Niimi, A.J. Economic and environmental issues of the proposed extension of the winter navigation season and improvements on the Great Lakes-St. Lawrence Seaway system. Journal of Great Lakes Research 1982, $8,532-549$

7. Vanderploeg, H.A.; Bolsenga, S.J;; Fahnenstiel, G.L.; Liebig, J.R.; Gardner, W.S. Plankton Ecology in an Ice-Covered Bay of Lake-Michigan - Utilization of a Winter Phytoplankton Bloom by Reproducing Copepods. Hydrobiologia 1992, 243, 175-183.

8. Wang, J.; Bai, X.Z.; Hu, H.G.; Clites, A.; Colton, M.; Lofgren, B. Temporal and Spatial Variability of Great Lakes Ice Cover, 1973-2010. Journal of Climate 2012, 25, 1318-1329.

9. Peace, R.L.; Sykes, R.B. Mesoscale Study of a Lake Effect Snow Storm. Monthly Weather Review 1966, 94, 495-507.

10. Hjelmfelt, M.R. Numerical Study of the Influence of Environmental-Conditions on Lake-Effect Snowstorms over Lake-Michigan. Monthly Weather Review 1990, 118, 138-150.

11. Wright, D.M.; Posselt, D.J.; Steiner, A.L. Sensitivity of Lake-Effect Snowfall to Lake Ice Cover and Temperature in the Great Lakes Region. Monthly Weather Review 2013, 141, 670-689.

12. Miner, T.J.; Fritsch, J.M. Lake-effect rain events. Monthly Weather Review 1997, 125, 3231-3248.

13. Angel, J.R.; Isard, S.A. An observational study of the influence of the Great Lakes on the speed and intensity of passing cyclones. Monthly Weather Review 1997, 125, 2228-2237.

14. Angel, J.R.; Isard, S.A. The frequency and intensity of Great Lake cyclones. Journal of Climate 1998, $11,61-71$.

15. Sousounis, P.J.; Fritsch, J.M. Lake-Aggregate Mesoscale Disturbances .2. A Case-Study of the Effects on Regional and Synoptic-Scale Weather Systems. Bulletin of the American Meteorological Society 1994, $75,1793-1811$. 
16. Chuang, H.Y.; Sousounis, P.J. The impact of the prevailing synoptic situation on the lake-aggregate effect. Monthly Weather Review 2003, 131, 990-1010.

17. Xiao, C.L.; Lofgren, B.M.; Wang, J. WRF-based assessment of the Great Lakes' impact on cold season synoptic cyclones (Accepted). Atmospheric Research 2018

18. Li, X.P.; Zhong, S.Y.; Bian, X.D.; Heilman, W.E.; Luo, Y.; Dong, W.J. Hydroclimate and variability in the Great Lakes region as derived from the North American Regional Reanalysis. Journal of Geophysical Research-Atmospheres 2010, 115.

19. Bryan, A.M.; Steiner, A.L.; Posselt, D.J. Regional modeling of surface-atmosphere interactions and their impact on Great Lakes hydroclimate. Journal of Geophysical Research-Atmospheres 2015, 120, 1044-1064.

20. Danard, M.B.; Rao, G.V. Numerical Study of Effects of Great Lakes on a Winter Cyclone. Monthly Weather Review 1972, 100, 374-382.

21. Boudra, D.B. A Study of the Early Winter Effects of the Great-Lakes .1. Comparison of Very Fine Scale Numerical Simulations with Observed Data. Monthly Weather Review 1981, 109, 2507-2526.

22. Bonan, G.B. Sensitivity of a Gcm Simulation to Inclusion of Inland Water Surfaces. Journal of Climate 1995, 8, 2691-2704.

23. Liang, X.Z.; Kunkel, K.E.; Meehl, G.A.; Jones, R.G.; Wang, J.X.L. Regional climate models downscaling analysis of general circulation models present climate biases propagation into future change projections. Geophysical Research Letters 2008, 35.

24. Zhong, S.Y.; Li, X.P.; Bian, X.D.; Heilman, W.E.; Leung, L.R.; Gustafson, W.I. Evaluation of regional climate simulations over the Great Lakes region driven by three global data sets. Journal of Great Lakes Research 2012, 38, 212-225.

25. Mallard, M.S.; Nolte, C.G.; Spero, T.L.; Bullock, O.R.; Alapaty, K.; Herwehe, J.A.; Gula, J.; Bowden, J.H. Technical challenges and solutions in representing lakes when using WRF in downscaling applications. Geoscientific Model Development 2015, 8, 1085-1096.

26. Goyette, S.; McFarlane, N.A.; Flato, G.M. Application of the Canadian Regional Climate Model to the Laurentian Great Lakes region: Implementation of a lake model. Atmosphere-Ocean 2000, 38, 481-503.

27. Gula, J.; Peltier, W.R. Dynamical Downscaling over the Great Lakes Basin of North America Using the WRF Regional Climate Model: The Impact of the Great Lakes System on Regional Greenhouse Warming. Journal of Climate 2012, 25, 7723-7742.

28. Mallard, M.S.; Nolte, C.G.; Bullock, O.R.; Spero, T.L.; Gula, J. Using a coupled lake model with WRF for dynamical downscaling. Journal of Geophysical Research-Atmospheres 2014, 119, 7193-7208.

29. Notaro, M.; Bennington, V.; Lofgren, B. Dynamical Downscaling-Based Projections of Great Lakes Water Levels. Journal of Climate 2015, 28, 9721-9745.

30. Dupont, F.; Chittibabu, P.; Fortin, V.; Rao, Y.R.; Lu, Y.Y. Assessment of a NEMO-based hydrodynamic modelling system for the Great Lakes. Water Quality Research Journal of Canada 2012, 47, 198-214.

31. Xue, P.F.; Pal, J.S.; Ye, X.Y.; Lenters, J.D.; Huang, C.F.; Chu, P.Y. Improving the Simulation of Large Lakes in Regional Climate Modeling: Two-Way Lake-Atmosphere Coupling with a 3D Hydrodynamic Model of the Great Lakes. Journal of Climate 2017, 30, 1605-1627.

32. Peltier, W.R.; d'Orgeville, M.; Erler, A.R.; Xie, F.Y. Uncertainty in Future Summer Precipitation in the Laurentian Great Lakes Basin: Dynamical Downscaling and the Influence of Continental-Scale Processes on Regional Climate Change. Journal of Climate 2018, 31, 2651-2673.

33. Spero, T.L.; Nolte, C.G.; Bowden, J.H.; Mallard, M.S.; Herwehe, J.A. The Impact of Incongruous Lake Temperatures on Regional Climate Extremes Downscaled from the CMIP5 Archive Using the WRF Model. Journal of Climate 2016, 29, 839-853.

34. Lofgren, B.M. A model for simulation of the climate and hydrology of the Great Lakes basin. Journal of Geophysical Research-Atmospheres 2004, 109.

35. Skamarock, W.C.; Klemp, J.B.; Dudhia, J.; Gill, D.O.; Barker, D.M.; Wang, W.; Powers, J.G. A description of the advanced research WRF version 3. Report, National Center For Atmospheric Research Boulder Co Mesoscale and Microscale Meteorology Div, 2008.

36. Taylor, K.E.; Stouffer, R.J.; Meehl, G.A. An Overview of Cmip5 and the Experiment Design. Bulletin of the American Meteorological Society 2012, 93, 485-498.

37. Hong, S.Y.; Noh, Y.; Dudhia, J. A new vertical diffusion package with an explicit treatment of entrainment processes. Monthly Weather Review 2006, 134, 2318-2341. 
38. Kain, J.S. The Kain-Fritsch convective parameterization: An update. Journal of Applied Meteorology 2004, 43, 170-181.

39. Iacono, M.J.; Delamere, J.S.; Mlawer, E.J.; Shephard, M.W.; Clough, S.A.; Collins, W.D. Radiative forcing by long-lived greenhouse gases: Calculations with the AER radiative transfer models. Journal of Geophysical Research-Atmospheres 2008, 113.

40. Janjic, Z.I. The Step-Mountain Eta Coordinate Model - Further Developments of the Convection, Viscous Sublayer, and Turbulence Closure Schemes. Monthly Weather Review 1994, 122, 927-945.

41. Oleson, K.W.; Lawrence, D.M.; Gordon, B.; Flanner, M.G.; Kluzek, E.; Peter, J.; Levis, S.; Swenson, S.C.; Thornton, E.; Feddema, J. Technical description of version 4.0 of the Community Land Model (CLM). Report, 2010.

42. Subin, Z.M.; Riley, W.J.; Mironov, D. An improved lake model for climate simulations: Model structure, evaluation, and sensitivity analyses in CESM1. Journal of Advances in Modeling Earth Systems 2012, 4.

43. Gu, H.P.; Jin, J.M.; Wu, Y.H.; Ek, M.B.; Subin, Z.M. Calibration and validation of lake surface temperature simulations with the coupled WRF-lake model. Climatic Change 2015, 129, 471-483.

44. Hostetler, S.W.; Bartlein, P.J. Simulation of Lake Evaporation with Application to Modeling Lake Level Variations of Harney-Malheur Lake, Oregon. Water Resources Research 1990, 26, 2603-2612.

45. Xiao, C.L.; Lofgren, B.M.; Wang, J.; Chu, P.Y. Improving the lake scheme within a coupled WRF-lake model in the Laurentian Great Lakes. Journal of Advances in Modeling Earth Systems 2016, 8, 1969-1985.

46. Kalnay, E.; Kanamitsu, M.; Kistler, R.; Collins, W.; Deaven, D.; Gandin, L.; Iredell, M.; Saha, S.; White, G.; Woollen, J.; Zhu, Y.; Chelliah, M.; Ebisuzaki, W.; Higgins, W.; Janowiak, J.; Mo, K.C.; Ropelewski, C.; Wang, J.; Leetmaa, A.; Reynolds, R.; Jenne, R.; Joseph, D. The NCEP/NCAR 40-year reanalysis project. Bulletin of the American Meteorological Society 1996, 77, 437-471.

47. Adler, R.F.; Huffman, G.J.; Chang, A.; Ferraro, R.; Xie, P.P.; Janowiak, J.; Rudolf, B.; Schneider, U.; Curtis, S.; Bolvin, D.; Gruber, A.; Susskind, J.; Arkin, P.; Nelkin, E. The version-2 global precipitation climatology project (GPCP) monthly precipitation analysis (1979-present). Journal of Hydrometeorology 2003, 4, 1147-1167. 48. Schwab, D.J.; Leshkevich, G.A.; Muhr, G.C. Satellite Measurements of Surface-Water Temperature in the Great-Lakes - Great-Lakes Coastwatch. Journal of Great Lakes Research 1992, 18, 247-258.

49. Lo, J.C.F.; Yang, Z.L.; Pielke, R.A. Assessment of three dynamical climate downscaling methods using the Weather Research and Forecasting (WRF) model. Journal of Geophysical Research-Atmospheres 2008, 113.

50. Heikkila, U.; Sandvik, A.; Sorteberg, A. Dynamical downscaling of ERA-40 in complex terrain using the WRF regional climate model. Climate Dynamics 2011, 37, 1551-1564.

51. Harding, K.J.; Snyder, P.K.; Liess, S. Use of dynamical downscaling to improve the simulation of Central US warm season precipitation in CMIP5 models. Journal of Geophysical Research-Atmospheres 2013, 118, 12522-12536.

52. Music, B.; Frigon, A.; Lofgren, B.; Turcotte, R.; Cyr, J.F. Present and future Laurentian Great Lakes hydroclimatic conditions as simulated by regional climate models with an emphasis on Lake Michigan-Huron. Climatic Change 2015, 130, 603-618.

53. Steiger, S.M.; Hamilton, R.; Keeler, J.; Orville, R.E. Lake-Effect Thunderstorms in the Lower Great Lakes. Journal of Applied Meteorology and Climatology 2009, 48, 889-902.

54. IPCC. Climate Change 2007: The Physical Science Basis. Report, 2007.

55. Holman, K.D.; Gronewold, A.; Notaro, M.; Zarrin, A. Improving historical precipitation estimates over the Lake Superior basin. Geophysical Research Letters 2012, 39.

56. Yang, B.; Qian, Y.; Lin, G.; Leung, R.; Zhang, Y. Some issues in uncertainty quantification and parameter tuning: a case study of convective parameterization scheme in the WRF regional climate model. Atmospheric Chemistry and Physics 2012, 12, 2409-2427.

57. Lambert, S.J.; Boer, G.J. CMIP1 evaluation and intercomparison of coupled climate models. Climate Dynamics 2001, 17, 83-106.

58. Held, I.M.; Soden, B.J. Robust responses of the hydrological cycle to global warming. Journal of Climate 2006, 19, 5686-5699.

59. O'Reilly, C.M.; Sharma, S.; Gray, D.K.; Hampton, S.E.; Read, J.S.; Rowley, R.J.; Schneider, P.; Lenters, J.D.; McIntyre, P.B.; Kraemer, B.M.; Weyhenmeyer, G.A.; Straile, D.; Dong, B.; Adrian, R.; Allan, M.G.; Anneville, O.; Arvola, L.; Austin, J.; Bailey, J.L.; Baron, J.S.; Brookes, J.D.; de Eyto, E.; Dokulil, M.T.; Hamilton, D.P.; Havens, K.; Hetherington, A.L.; Higgins, S.N.; Hook, S.; Izmest'eva, L.R.; Joehnk, K.D.; Kangur, K.; 
$500 \quad$ Kasprzak, P.; Kumagai, M.; Kuusisto, E.; Leshkevich, G.; Livingstone, D.M.; MacIntyre, S.; May, L.; Melack, 501 J.M.; Mueller-Navarra, D.C.; Naumenko, M.; Noges, P.; Noges, T.; North, R.P.; Plisnier, P.D.; Rigosi, A.; 502 Rimmer, A.; Rogora, M.; Rudstam, L.G.; Rusak, J.A.; Salmaso, N.; Samal, N.R.; Schindler, D.E.; Schladow, 503 S.G.; Schmid, M.; Schmidt, S.R.; Silow, E.; Soylu, M.E.; Teubner, K.; Verburg, P.; Voutilainen, A.; Watkinson, 504 A.; Williamson, C.E.; Zhang, G.Q. Rapid and highly variable warming of lake surface waters around the $505 \quad$ globe. Geophysical Research Letters 2015, 42, 10773-10781.

506 60. Zhong, Y.F.; Notaro, M.; Vavrus, S.J.; Foster, M.J. Recent accelerated warming of the Laurentian Great 507 Lakes: Physical drivers. Limnology and Oceanography 2016, 61, 1762-1786. 